Research \&

Deveiopment Program

\title{
Non-fertile Fuels Development for Plutonium and High-Enriched Uranium Dispositioning in Water Cooled Reactors
}

C. S. Olsen

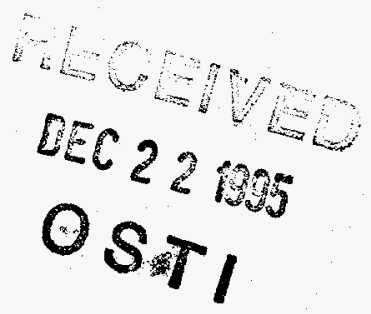

Idaho National Engineering Laboratory

P. O. Box 1625

Idaho Falls, Idaho 83415-3890

September 1994

Prepared for the

U. S. Department of Energy

through the INEL LDRD Program

Under DOE Idaho Operations Office

Contract DE-AC07-94ID13223
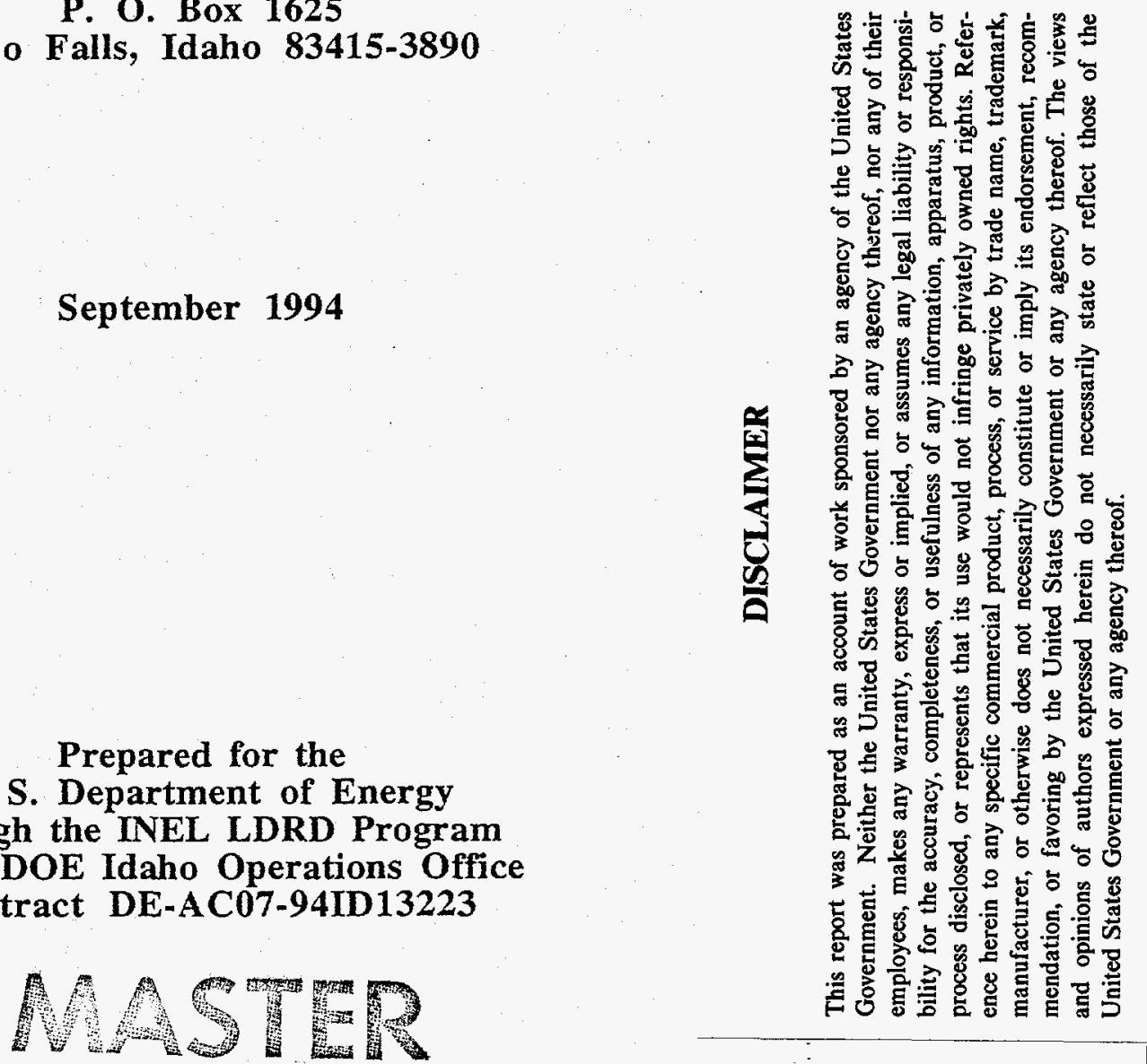


\section{DISCLAMIER}

Portions of this document may be illegible in electronic image products. Images are produced from the best available original document. 


\begin{abstract}
As a result of dismantling the bomb, there is about $100 \mathrm{MT}$ of excess weapons grade plutonium in the United States and about $150 \mathrm{MT}$ in the Commonwealth of Independent States. In addition, there is another $1000 \mathrm{MT}$ of plutonium in commercial spent fuel that may be used as degraded weapons material. One means to disposition weapons grade plutonium is by irradiating the fuel in light water reactors (LWRs) using a non-fertile fuel based on plutonia dispersed in an oxide mixture of zirconia stabilized with calcia or yttria as a solid solution. Plutonium dispersed in a zirconia matrix offers the potential to achieve very high burnups while maintaining mechanical integrity.
\end{abstract}

A potential improvement is based on replacing the calcia with yttria and reducing the yttria content to form a partially stabilized zirconia that may have a higher resistance to cracking. A rare-earth element is also added as a burnable poison to enhance the lifetime of the fuel and the neutronic characteristics. Yttria lowers the tetragonal to monoclinic transformation temperature to $275^{\circ} \mathrm{C}$ compared with $850^{\circ} \mathrm{C}$ for calcia. In addition, yttria does not significantly reduce the melting point of the solid soluton from that of zirconia near $2700^{\circ} \mathrm{C}$. However, if the mechanical properties of partially stabilized zirconia with yttria proves favorable, the yttria content may be reduced resulting in higher thermal conductivity of the ternary fuel.

The use of urania-zirconia-calcia fuels with high uranium concentration in three reactors during the 1970 s and 1980s established a basis for the development of a plutonia-zirconia-calcia fuel and a urania-zirconia-calcia fuel with lower concentrations of uranium than that previously used. The existing data on phase equilibria of the plutonia-zirconia-calcia or yttria and the urania-zirconiacalcia or -yttria systems were obtained and evaluated for feasible fissile concentrations and concentrations of the matrix materials. Based on the urania ternary fuels and neutronic calculations, the composition of the ternary fuel containing plutonia is $8.3 \mathrm{wt} \%$ plutonia, 80.4 wt\% zirconia, $9.7 \mathrm{wt} \%$ calcia, and $1.6 \%$ erbia. For yttria replacing calcia, the same fissile and erbia contents are retained, and the yttria content varies from $9.9 \mathrm{wt} \%$ to $30.4 \mathrm{wt} \%$ with the zirconia varying from 80.2 to $59.7 \mathrm{wt} \%$.

Since the melting point of plutonia (about $2350^{\circ} \mathrm{C}$ ) is lower than that of $\mathrm{ZrO} 2$, the addition of zirconia increases the melting point of the fuel mixture about $125^{\circ} \mathrm{C}$. The ternary phase diagram for either the urania or plutonia based fuels using yttria in place of calcia could not be derived since the urania-yttria and the plutonia-yttria phase diagrams are needed and are not available. In addition, the plutonia-zirconia-calcia phase diagram could not be derived because the plutoniacalcia phase diagram is not available. Experimental determinations would have to be performed to obtain these phase diagrams. Although the phase diagrams are incomplete, sufficient data was available to indicate that plutonia may be better than even urania in forming a complete solid solution with zirconia.

A model to calculate density of a mixture of the constituents was developed for the addition of urania or plutonia to a stabilized zirconia mixture. Because the creation of anion vacancies from the addition of burnable poisons or stabilizing agents to zirconia, density estimates based on Vegard's law result in $20 \%$ higher values of density estimates than measured densities. The densities or lattice constants for the binary mixture of $\mathrm{ZrO}_{2}$ with calcia or one of the rare earth oxides is within $5 \%$ of the measured values, indicating the applicability of the model to binary mixtures of alkaline earth or rare earth oxides with zirconia. The results of adding urania or plutonia to binary mixtures of zirconia and calcia are not quite as good as those of the binary mixtures (7\% compared with $5 \%)$.

A theory has been developed for predicting transformation strengthening of partially stabilized zirconia (PSZ), and although the theory has been substantiated for zirconia stabilized with yttria, it 
has not been verified in all systems such as zirconia mixed with alumina. This increase in mechanical properties arises from improved microcracking resistance resulting from the blunting of cracks by the transformation of the tetragonal phase to the monoclinic phase. The use of yttria to stabilize zirconia instead of calcia appears to be a beneficial step because of the additional constraint that yttria offers and the lower transformation temperature. Although data are not available for the reduction of microcracking of fissile loaded zirconia-yttria alloys, the available data indicates that yttria will be a substantial improvement over calcia stabilized zirconia fuel matrix.

The mechanical integrity of the fuel matrix is enhanced by the selection of materials with low cross sections that will have a low propensity to irradiation damage. For this reason the selection of zirconia, calcia, or yttria all exhibit good irradiation resistance. On the other hand, inspite of its good thermal conductivity, alumina is extensively damaged by fission fragments when surrounded by a fissile material.

Literature values for the diffusion rates of noble gases in non-fertile matrix material indicates that the rate controlling step is diffusion through cation vacancies as is the case with urania-based fuels. These diffusion rates, which are about two orders of magnitude higher than those of urania, were used in the FASTGRASS code to predict fission gas release as a function of temperature.

Although the fission gas releases were slightly less than those of $\mathrm{UO}_{2}$ at low temperatures, the release exceeded those of $\mathrm{UO}_{2}$ at high temperatures. Fuel performance based on the non-fertile fuel design and using $\mathrm{UO}_{2}$ properties show fission gas releases less than $6 \%$, cladding strains less than the 1\% NRC limit, and internal fuel rod pressures remaining less than the coolant pressures. 


\section{Contents}

Abstract

Contents

1.0 Introduction

2.0 Zirconia-Based Fuels Phase Equilibria

3.0 Density Estimates of Advanced Ternary Fuels

3.1 Defect Structure

3.2 Density of Zirconia with the Addition of Stabilizing Oxides Calcia or Rare Earth Elements

3.3 Density of Stabilized Zirconia with Urania

4.0 Thermal Conductivity of $\mathrm{PuO}_{2}$ (or $\mathrm{UO}_{2}$ )-Stabilized $\mathrm{ZrO}_{2}$.

Mixtures Using $\mathrm{CaO}$ or $\mathrm{Y}_{2} \mathrm{O}_{3}$

4.1 Thermal Conduction of $\mathrm{UO}_{2}-\mathrm{ZrO}_{2}$ mixtures

4.2 Thermal Conductivity of $\mathrm{ZrO} 2$ Mixtures

4.3 Fuel Temperatures

5.0 Mechanical Behavior of Partially Stabilized Zirconia (PSZ)

6.0 Irradiation Behavior

7.0 Fuel Qualification

8.0 Conclusions

9.0 References 


\section{Figures}

1. Urania-Zirconia Pseudo binary Phase Diagram

2 Urania-Calcia Pseudo binary Phase Diagram

3 Zirconia-Calcia Pseudo binary Phase Diagram

4 Urania-Zirconia-Calcia Pseudo binary Phase Diagram

5 Plutonia-Zirconia Pseudo binary Phase Diagram

6 Zirconia-Yittria Phase Diagram

7 Thermal diffusivity of $\mathrm{UO}_{2}-\mathrm{ZrO}_{2}$ binary mixtures

8 Thermal conductivity of $\mathrm{ZrO}_{2}-\mathrm{UO}_{2}$ mixtures.

9 Thermal conductivity of $\mathrm{UO}_{2}-\mathrm{ZrO}_{2}-\mathrm{CaO}$ mixtures

10 Effect of calcia on $\mathrm{ZrO}_{2}$ conductivity

11 Fracture strength of partially stabilized zirconia with yttria

12 Comparison of fission gas release between UO2 and non-fertile fuel. 


\section{Tables}

1. Composition of stabilized solid solution using calcia

2. Composition of stabilized and partially stabilized solid solution using yttria

3 Stabilizing Elements and Their Properties

4 Comparison of Density for $\mathrm{ZrO}_{2}-\mathrm{CaO}$ Mixtures

5 Comparison of Density for $\mathrm{ZrO}_{2}-\mathrm{Y}_{2} \mathrm{O}_{3}$ Mixtures

6 Comparison of Lattice Parameter for $\mathrm{ZrO}_{2}-\mathrm{Er}_{2} \mathrm{O}_{3}$ Mixtures

7 Density of $\mathrm{ZrO}_{2}-\mathrm{Gd}_{2} \mathrm{O}_{3}$ Mixtures

8 Lattice Constant for mixtures of $\mathrm{UO}_{2}$ with $\mathrm{ZrO}_{2}$ and $\mathrm{CaO}$

9 Density for mixtures of $\mathrm{UO}_{2}$ with $\mathrm{ZrO}_{2}$ and $\mathrm{CaO}$

10 Comparison of Measured and Calculated Lattice Parameter for Mixtures of $\mathrm{UO}_{2}$ and $\mathrm{ZrO}_{2}$ Stabilized with $\mathrm{CaO}$

11 Comparison of Measured and Calculated Density for Mixtures of $\mathrm{UO}_{2} \ldots \ldots . .$. and $\mathrm{ZrO}_{2}$ Stabilized with $\mathrm{CaO}$

12 Lattice Parameter for mixtures of $\mathrm{PuO}_{2}$ with $\mathrm{ZrO}_{2}$ and $\mathrm{CaO}$

13 Density for mixtures of $\mathrm{PuO}_{2}$ with $\mathrm{ZrO}_{2}$ and $\mathrm{CaO}$

14 Fuel temperatures for various annular hole sizes for PWR fuel pellets

15 Fuel temperatures for various annular hole sizes for BWR fuel pellets

16 Measured diffusion coefficients for cation diffusion 


\subsection{Introduction}

As a result of dismantling the bomb, there is about $100 \mathrm{MT}$ of excess weapons grade plutonium in the United States and about $150 \mathrm{MT}$ in the Commonwealth of Independent States. In addition, there is another $1000 \mathrm{MT}$ of plutonium in commercial spent fuel that may be used as degraded weapons material. Nuclear Weapons in both the United States and Commonwealth of Independent States (CIS) will be dismantled as a result of recent nuclear arms reduction agreements, $[1,2]$ and plutonium removed from these weapons must be dispositioned in a manner that will prevent future use for hostile purposes.

Of the various methods proposed for denaturing or annihilating the surplus plutonium stock pile possessed by the United States, one means to disposition weapons grade or reactor grade plutonium is by irradiating the fuel in light water reactor (LWR) using a non-fertile fuel based on plutonia dispersed in an oxide mixture of zirconia stabilized with calcia or yttria as a solid solution. Plutonium dispersed in a zirconia matrix offers the potential to achieve very high burnups while maintaining mechanical integrity. A basis for this fuel has already been established in which zirconia has been used with $\mathrm{UO}_{2}$ fuels for the Power Burst Facility, the Savannah River Reactor, and a light-water breeder reactor [3]. A potential improvement is based on replacing the calcia with yttria and reducing the yttria content to form a partially stabilized zirconia that may have a higher resistance to cracking. A rare-earth element is also added as a burnable poison to enhance the lifetime of the fuel and the neutronic characteristics.

Because a fertile material such as $238 \mathrm{U}$ is not required this fuel may also use high-enriched uranium (HEU) with $93 \%$ enriched ${ }^{235} \mathrm{U}$ instead of plutonia.

The characteristics of this non-fertile fuel is discussed with regard to its fuel performance behavior. The neutronic behavior has been documented in a separate publication. [4] A strategy for developing this fuel is also presented.

The fuel is designed for a PWR $17 \times 17$ fuel design and a BWR $8 \times 8$ fuel design (Table 1). The fuel is based on $8.3 \mathrm{wt} \% \mathrm{PuO}_{2}$ which could also be the same content of $\mathrm{UO}_{2}$ containing highenriched-uranium (HEU).

Table 1. Composition of stabilized solid solution using calcia

\begin{tabular}{||ccc|}
\hline \hline Parameter & $\underline{\text { PWR }}$ & $\underline{\text { BWR }}$ \\
Cladding & Zircaloy-2 & Zircaloy-4 \\
Outside Diameter $(\mathrm{cm})$ & 0.9498 & 1.2258 \\
Inside Diameter $(\mathrm{cm})$ & 0.8354 & 1.0643 \\
Fuel Diameter & 0.8189 & 1.0434 \\
Radial Gas Gap & 0.00826 & 0.0104 \\
Pitch (cm) & 1.25 & 1.6256 \\
Composition (wt \%) & 8.3 & 8.3 \\
PuO2 & 80.4 & 80.4 \\
$\mathrm{ZrO} 2$ & 9.7 & 8.3 \\
$\mathrm{CaO}$ & 1.6 & 1.6 \\
$\mathrm{Er}_{2} \mathrm{O}_{3}$ & & \\
\hline
\end{tabular}

This composition ensures a completely stabilized zirconia with 20 mole\% calcia resulting in a cubic solid solution. An improved fuel design may be developed by substituting calcia with yttria. The tentative composition for this fuel is shown in Table 2 for completely stabilized cubic solid solution 
containing $20.4 \mathrm{wt} \%$ yttria (20.6 mole\%) and partially stabilized zirconia (PSZ) containing as low as $9.9 \mathrm{wt} \%$ yttria (6.0 mole\% yttria). The basis for the partially stabilized structure is described below under mechanical integrity.

Table 2. Composition of stabilized and partially stabilized solid solution using yttria

\begin{tabular}{|lrr||}
\hline Parameter & \multicolumn{1}{c|}{ PWR } & \multicolumn{1}{c|}{ ZWR } \\
Cladding & 0.9498 & Zircaloy-4 \\
Outside Diameter $(\mathrm{cm})$ & 0.8354 & 1.2258 \\
Inside Diameter $(\mathrm{cm})$ & 0.190 & 1.0643 \\
Fuel Diameter & 0.00826 & 1.0434 \\
Radial Gas Gap & 1.25 & 0.0104 \\
Pitch $(\mathrm{cm})$ & & 1.6256 \\
Composition (wt \$\%) & 8.3 & 8.3 \\
$\mathrm{PuO}_{2}$ & 80.2 to 59.7 & 80.2 to 59.7 \\
$\mathrm{ZrO}_{2}$ & 9.9 to 30.4 & 9.9 to 30.4 \\
$\mathrm{Y}_{2} \mathrm{O}_{3}$ & 1.6 & 1.6 \\
$\mathrm{Er}_{2} \mathrm{O}_{3}$ & & \\
\hline
\end{tabular}




\subsection{Zirconia-Based Fuels Phase Equilibria}

At atmospheric pressure, $\mathrm{ZrO}_{2}$ undergoes phase changes from monoclinic to tetragonal between 950 and $1150{ }^{\circ} \mathrm{C}$ and from tetragonal to cubic (fluorite structure) at about $2300{ }^{\circ} \mathrm{C}$. The monoclinic to tetragonal transformation exhibits a substantial amount of hysteresis and a large $3 \%$ volume change between heating and cooling. The transformation is diffusionless (martensitic), and the origin of the large hysteresis is explained by strain energy considerations in the transforming crystal lattice. The large volume change associated with the transformation gives rise to internal stresses upon heating and cooling. The monoclinic to tetragonal transformation is particularly physically deleterious to the ceramic structure. [5] Doping of $\mathrm{ZrO}_{2}$ with small additions of $\mathrm{CaO}$, $\mathrm{MgO}$, or rare earths such as $\mathrm{Y}_{2} \mathrm{O}_{3}$ can be used to lower the two transition temperatures in $\mathrm{ZrO}_{2}$ and stabilize the cubic fluorite structure at high temperatures and eliminate the large volume changes during phase changes.

In a parallel fashion to the development of ternary $\mathrm{UO}_{2}-\mathrm{ZrO}_{2}-\mathrm{CaO}$ fuels, $\mathrm{PuO}_{2}$ may be substituted for $\mathrm{UO}_{2}$ in order to achieve high burnup fuel capability $\left(7.45 \times 10^{20}\right.$ fissions $\left./ \mathrm{cm}^{3}\right)$ and still retain structural integrity. Although burnable poisons such as erbia or gadolinia may be used to stabilize a cubic structure, large quantities of bumable poisons require large amounts of plutonium to compensate for reactivity. The plutonium will not be completely burned and would therefore require fuel reprocessing. However, small amounts of the rare earths may be added to enhance the neutronic performance and contribute to stabilizing the structure.

For the $\mathrm{UO}_{2}-\mathrm{ZrO}_{2}-\mathrm{CaO}$ fuel system, the pseudo binary phase diagrams required to support this system are the $\mathrm{UO}_{2}-\mathrm{ZrO}_{2}, \mathrm{UO}_{2}-\mathrm{CaO}$, and the $\mathrm{ZrO}_{2}-\mathrm{CaO}$ phase diagrams shown in Figures 1,2 and 3. 6-9] These diagrams along with experimental measurements identifies the composition range to achieve the stabilized, single phase solid solution range for a ternary fuel. This region used for solid solution ternary fuels is shown in Figure 4. ${ }^{[5]}$

From the $\mathrm{ZrO}_{2}-\mathrm{CaO}$ phase diagram shown in Figure 3, about 15 mole\% calcia is required to stabilize the cubic structure, but in considering the ternary phase diagram, the calcia content has to be increased to $9.7 \mathrm{wt} \%$ (20.1 mole\% calcia) and the zirconia content correspondingly decreased to maintain the single-phase, cubic solid solution. This composition is assumed to be the same composition for plutonia ternary fuels.

The pseudo binary as well as the ternary diagrams assume stochiometric phases. The uraniazirconia phase diagram (Figure 1) exhibits a two phase structure, a low-urania cubic structure and a high zirconia tetragonal to monoclinic structure. The liquidus temperature for the binary system with about 80 mole\% zirconia is about $2500^{\circ} \mathrm{C}, 240^{\circ} \mathrm{C}$ lower than the melting point of urania. The addition of about 15 mole\% calcia (Figure 3) stabilizes the tetragonal zirconia structure in the cubic fluorite structure. The zirconia-calcia phase diagram exhibits a tetragonal to monoclinic transformation near $850^{\circ} \mathrm{C}$.

For the plutonia-zirconia-calcia system, not all of the phase diagrams that are needed are available. The plutonia-zirconia phase diagram is shown in Figure 5. $[10]$ The high-zirconia region exhibits the monoclinic structure of zirconia at concentrations greater than 77 mole\%. The addition of zirconia acts to increase the liquidus temperature to about $2425^{\circ} \mathrm{C}$ compared with the $2350^{\circ} \mathrm{C}$ melting point of plutonia. The zirconia-calcia phase diagram (Figure 3 ) indicates $15 \mathrm{~mole} \%$ calcia is needed to stabilize the zirconia structure. The phase-diagram that is missing is the plutonia-calcia phase diagram. 


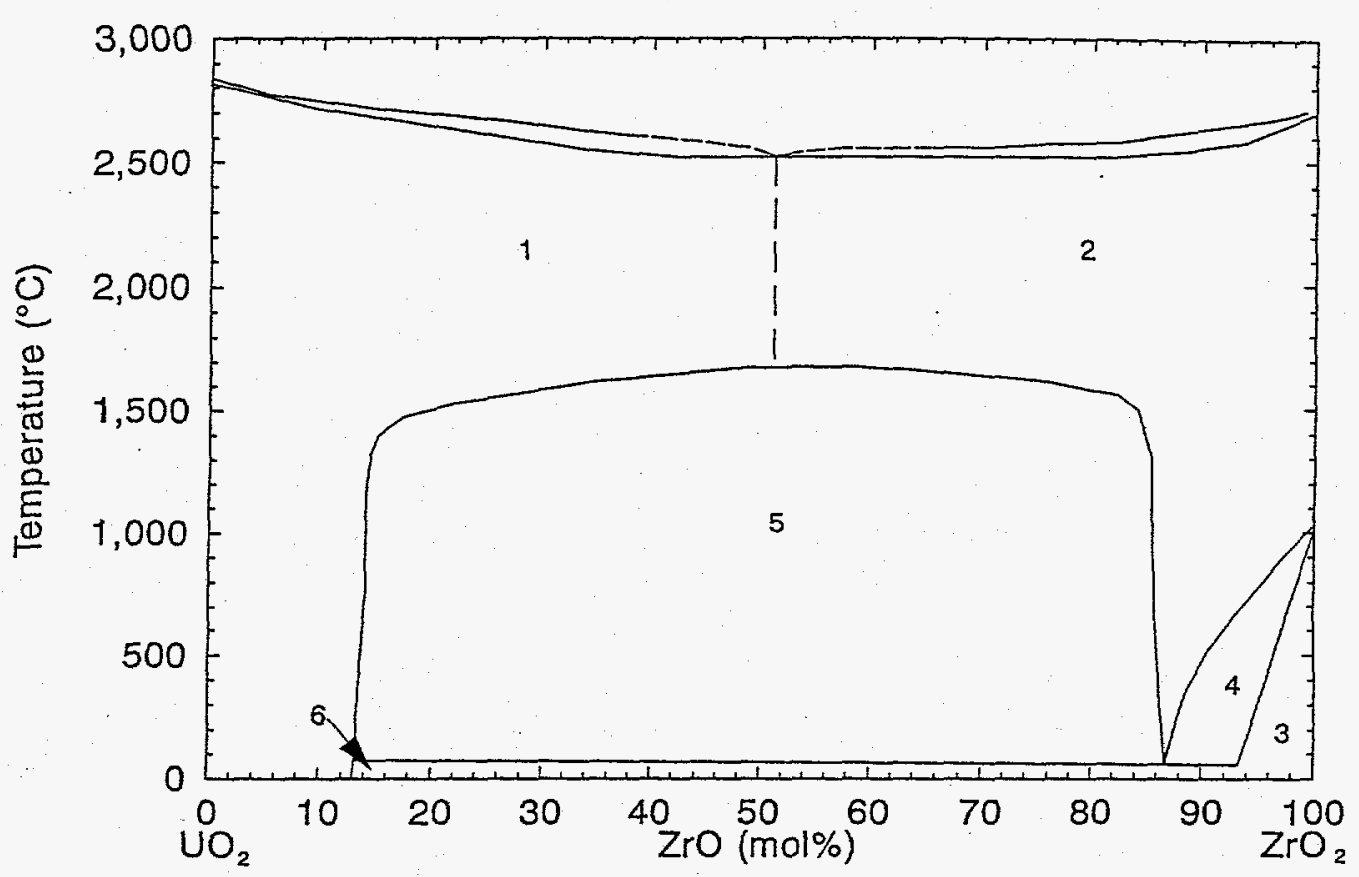

1. Face-centered cubic solid solution

2. Tetragonal solid solution

3. Monoclinic solid solution

4. Monoclinic solid solution + tetragonal solid solution

5. Face-centered solid solution + tetragonal solid solution

6. Face-centered solid solution + monoclinic solution

2516 cso-1294-01

Figure 1 Urania-Zirconia Pseudo binary Phase Diagram 


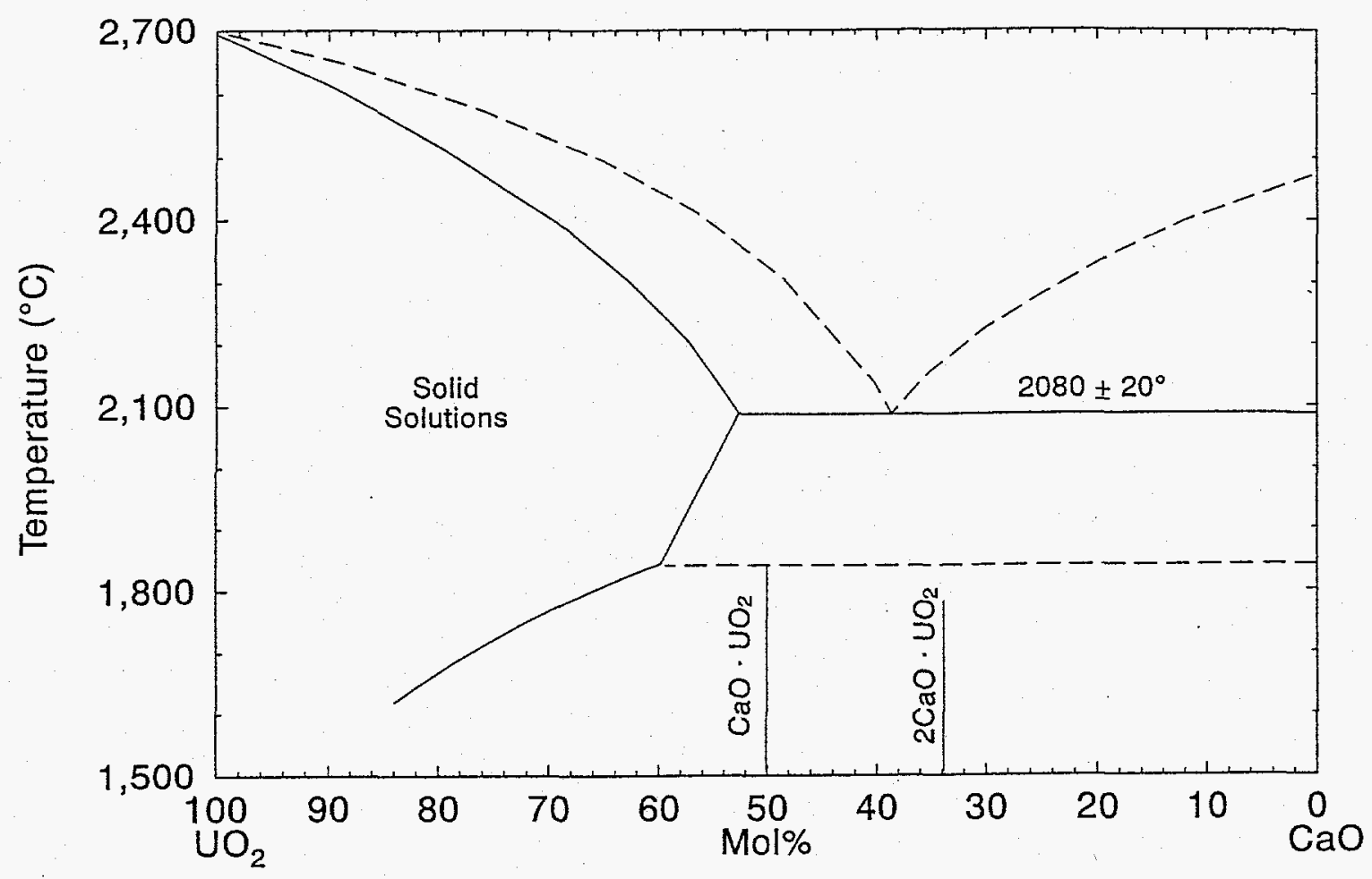

Figure 2 Urania-Calcia Pseudo binary Phase Diagram

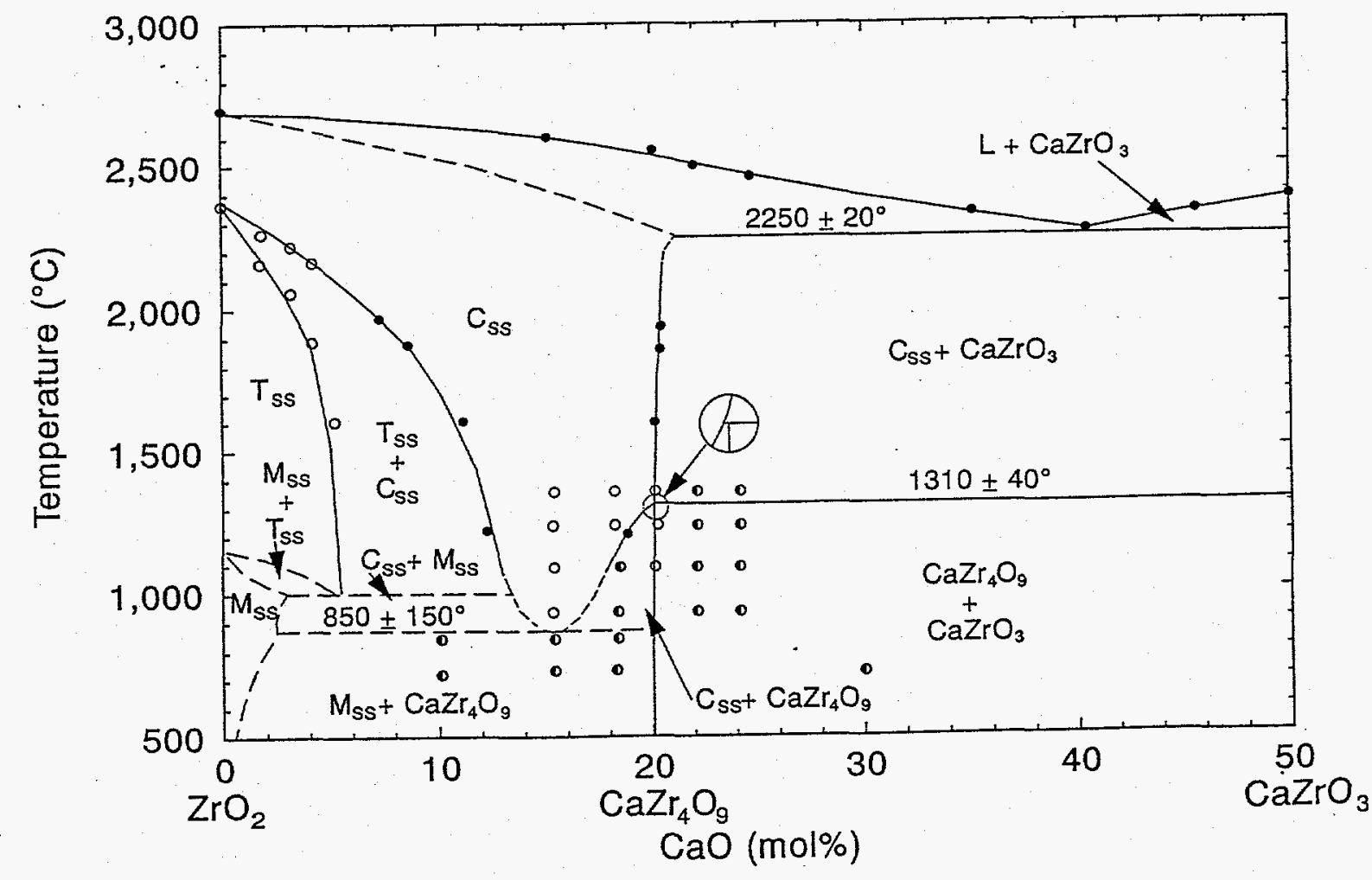

Figure 3 Zirconia-Calcia Pseudo binary Phase Diagram 


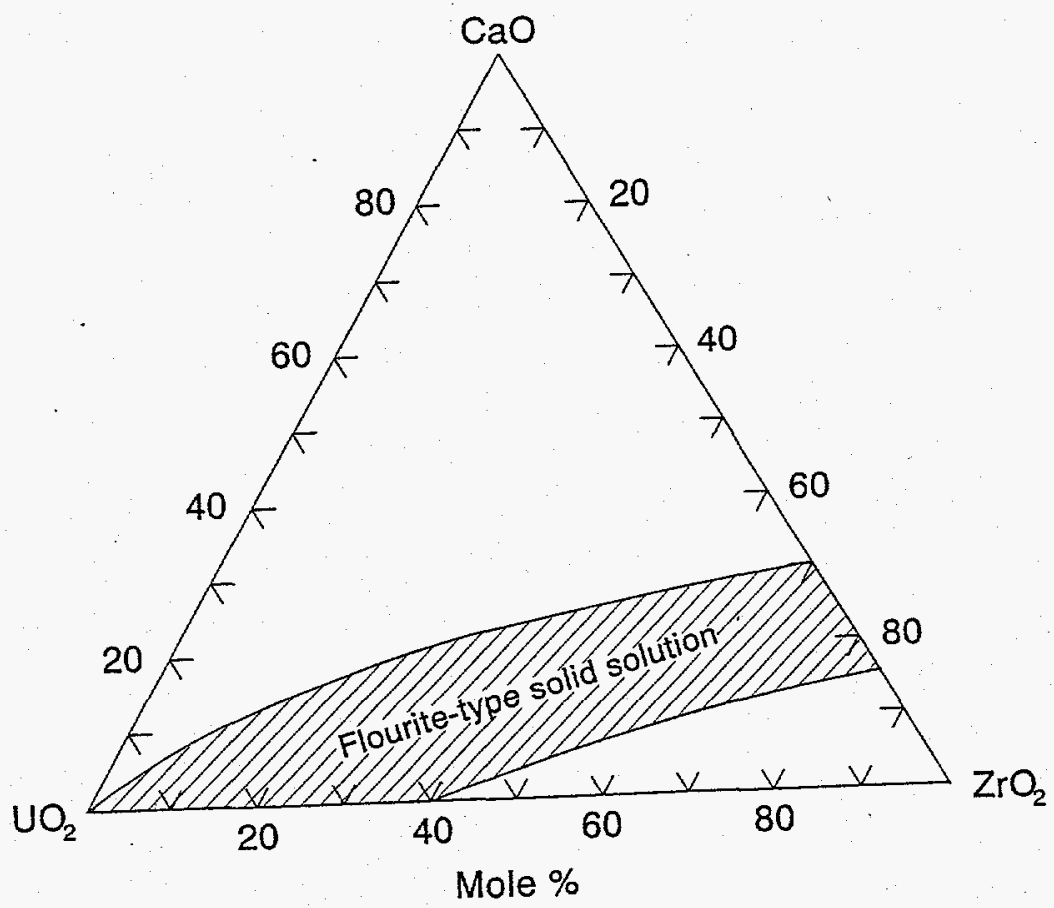

2516 cosolos-05

Figure 4 Urania-Zirconia-Calcia Pseudo binary Phase Diagram

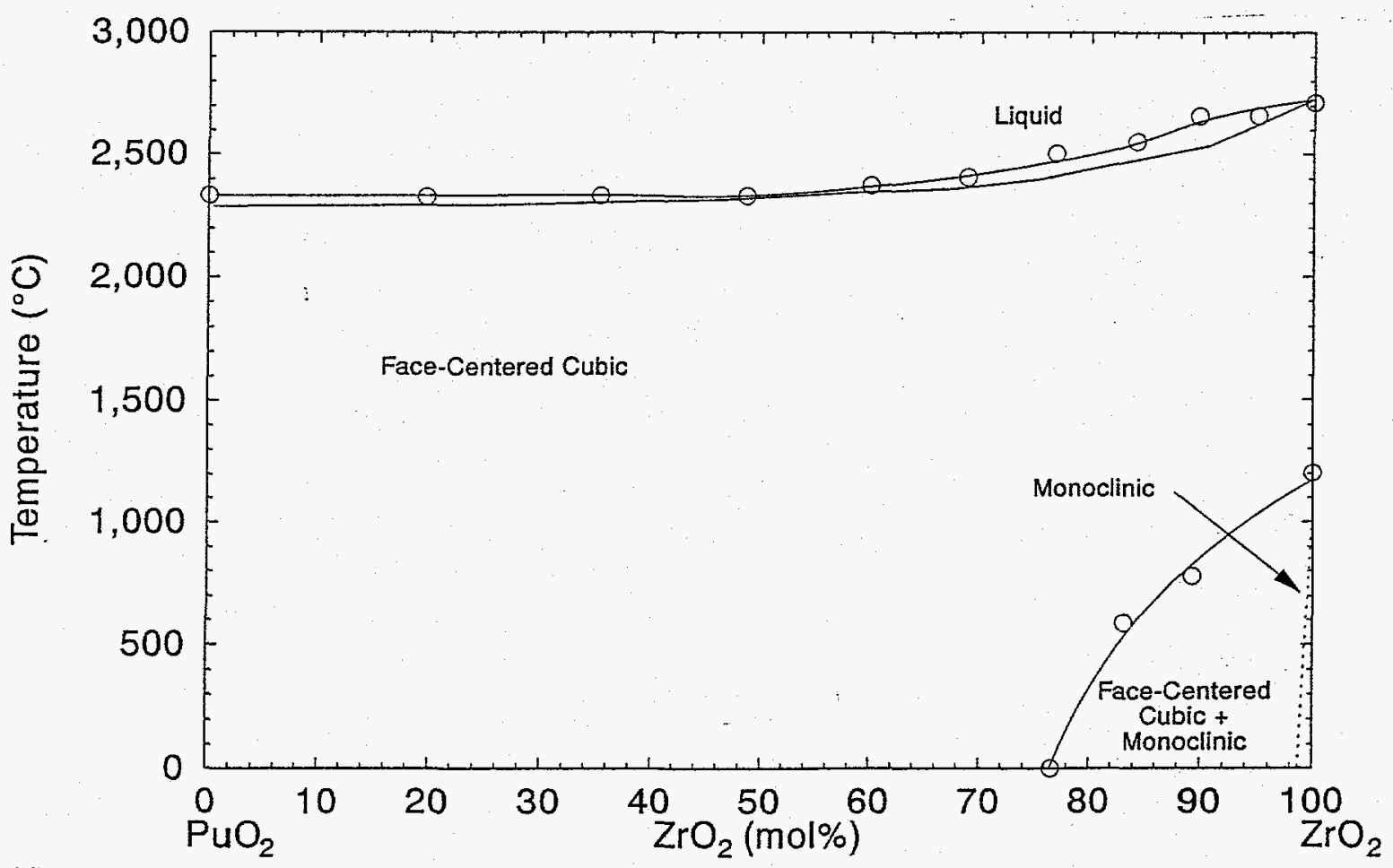

Figure 5 Plutonia-Zirconia Pseudo binary Phase Diagram 
The substitution of yttria for calcia lowers the tetragonal to monoclinic transformation temperature to $275^{\circ} \mathrm{C}$ compared with $850^{\circ} \mathrm{C}$ for the zirconia-calcia system (Figure 6). [11] Although yttria in the amount of about 20 mole\% (30.4 wt\%) stabilizes the fluorite cubic structure, smaller amounts ( 6 mole\%, $9.9 \mathrm{wt} \%$ yttria) that yield a partially stabilized structure may offer improved cracking resistance by the transformation of a smaller amount of tetragonal transformation to the monoclinic structure. The phase diagrams that are needed for the urania and plutonia systems are the uraniayittria and the plutonia-yittria phase diagrams.

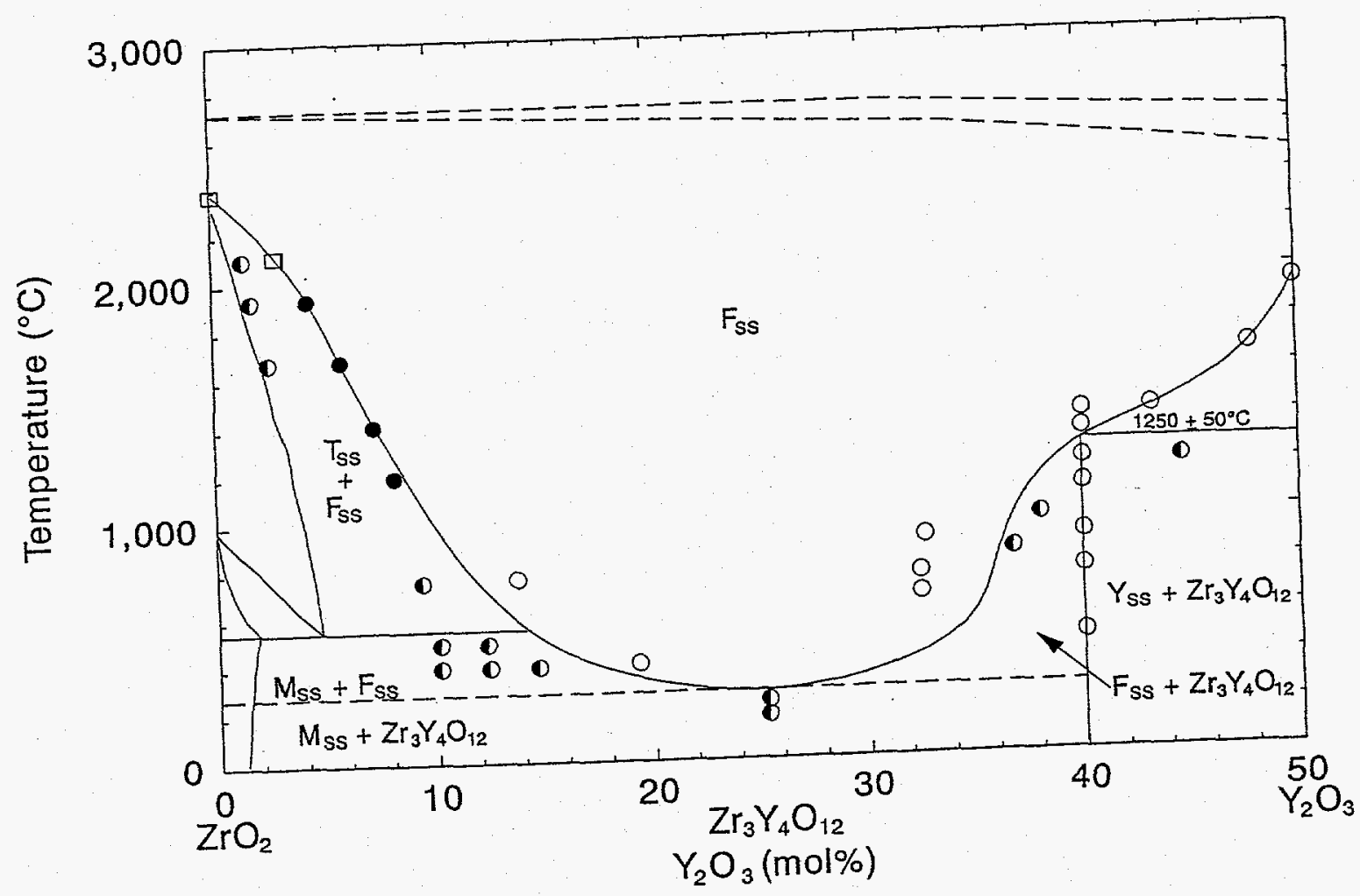

Figure 6 Zirconia-Yittria Phase Diagram 


\subsection{Density Estimates of Advanced Ternary Fuels}

Because the components have different crystallographic structures at room temperatures, a method is discussed to estimate the density of binary mixtures of zirconia with other stabilizing oxides, then the density of these structures with the addition of urania, and finally with the additions of plutonia replacing the urania is estimated.

\subsection{Defect Structure}

The addition of calcia or yttria to zirconia results in a lattice defect structure in order to maintain charge neutrality from the addition of the +2 calcium cation or the +3 yttrium (or other rare earth) cation. These additions could result in the creation of cation interstitials or oxygen vacancies. For the fluorite structure, a comparison of measured versus calculated densities shows the creation of oxygen vacancies according to Equations 1 and 2 for calcia and yttria, respectively,.

$$
\begin{aligned}
& \mathrm{ZrO}_{2}^{\text {null }}+\mathrm{CaO} \rightarrow \mathrm{ZrO}_{2}^{\text {null }}+\mathrm{Ca}^{+2}+\mathrm{O}_{\mathrm{V}}+2 e^{-}+\frac{1}{2} \mathrm{O}_{2} \\
& \mathrm{ZrO}_{2}^{\text {null }}+\mathrm{Y}_{2} \mathrm{O}_{3} \rightarrow \mathrm{ZrO}_{2}^{\text {null }}+2 \mathrm{Y}^{+3}+2 \mathrm{O}^{-2}+\mathrm{O}_{\mathrm{V}}+2 e^{-}+\frac{1}{2} \mathrm{O}_{2}
\end{aligned}
$$

The oxygen deficiency through oxygen vacancies $\left(\mathrm{O}_{\mathrm{v}}\right)$ in the lattice lowers the density compared with that predicted from a perfect crystal with all of the lattice positions filled. The defect structure is another reason beside the different crystal structures why the rule of mixtures over predicts the density of these structures.

A model was developed ${ }^{[12]}$ that is based on the crystallographic structure of $\mathrm{CaF}_{2}$, fluorite (Figure 7). Cubic zirconia exhibits the same structure with differing amounts of stabilizing elements. The density model assumes spherical packing of ions and utilizes the calculated mean number of anion vacancies per unit cell. In conjunction with this model, an equation was developed for the calculation of the theoretical density of stabilized $\mathrm{ZrO}_{2}$ cubic solid solution based on a substitutional model which takes into account the vacancies formed by stabilizers with valences different than $\mathrm{Zr}^{+4}$.

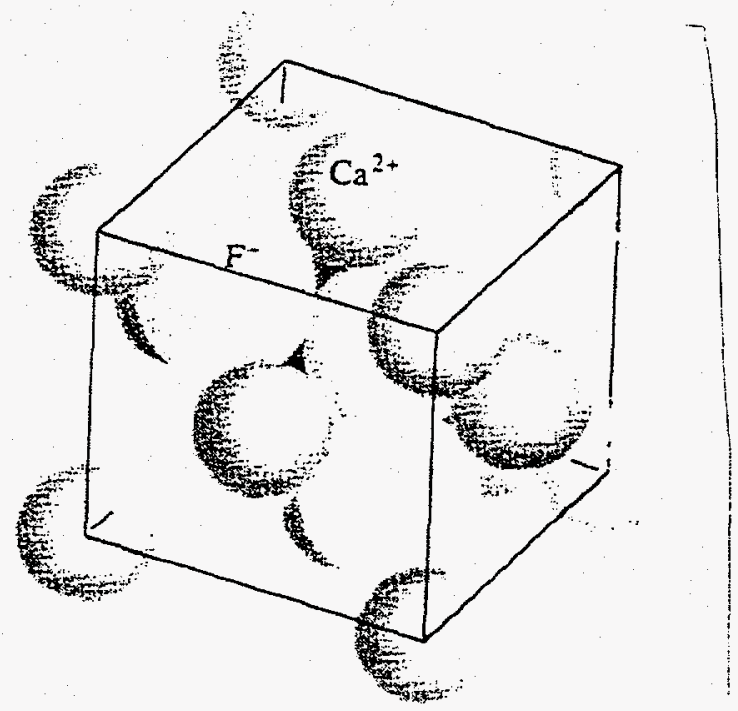

Figure 7 Fluorite structure of $\mathrm{CaF}_{2}, \mathrm{ZrO}_{2}$, and $\mathrm{UO}_{2}$ 
The density (mass/volume) is derived from the size of the unit cell which yields the volume of the crystal structure and then the appropriate atomic masses of the elements are used to calculate the mass in the density equation.

The equation to calculate the lattice constant for $\mathrm{ZrO}_{2}$ stabilized by different amounts of elements follows:

$$
d_{O}=0.1 A\left[R_{Z r}+R_{O}+\frac{\Sigma\left(P_{k} M_{k} \Delta R_{k}\right)}{100+\sum M_{k}\left(P_{k}-1\right)}\right]
$$

The sum is over all the stabilizing elements where $\mathrm{R}_{\mathrm{Zr}}$ and $\mathrm{R}_{\mathrm{O}}$ are the ionic radii of $\mathrm{Zr}^{+4}$ and $\mathrm{O}^{-2}$, respectively, $\mathrm{R}_{\mathrm{k}}$ is the ionic radius of the $\mathrm{kth}$ stabilizer ionic, and $\mathrm{M}_{\mathrm{k}}$ is the mole percentage of the $\mathrm{k}_{\mathrm{th}}$ stabilizer. The term $\mathrm{P}_{\mathrm{k}}$ is the number of ions per unit cell of each stabilizing element in the oxide. The constant $A$ is based on the geometry of the unit cell of the fluorite structure, i.e.

$$
A=\frac{4}{\sqrt{3}}=2.3094
$$

Using the dimension of the unit cell give by Equation 3, the density of the solid solution of a stabilizing oxide with zirconia is given by:

$$
\rho=\left[A_{\mathrm{Zr}}+2 A_{o}+\frac{\sum P_{k} M_{k}\left(\Delta A_{k}+\left\{\left(P_{o k} / P_{k}\right)-2\right\} A_{o}\right)}{100+\sum M_{k}\left(P_{k}-1\right)}\right] x\left\{\frac{Z}{10^{-24} N d_{o}^{3}}\right\}
$$

where $A_{Z r}$ is the gram atomic weight of zirconium

$\mathrm{A}_{\mathrm{O}}$ is the gram atomic weight of oxygen

$\Delta \mathrm{A}_{\mathrm{k}}$ is the difference between the gram atomic weight of the kth stabilizing element and that of $\mathrm{Zr}$

$\mathrm{N}$ is Avogadro's number $6.023 \times 10^{23} \mathrm{~mol}^{-1}$

$Z$ is the number of molecules per unit cell

$\mathrm{P}_{\mathrm{k}}$ is the number of ions per molecule of the stabilizing element

$\mathrm{P}_{\mathrm{Ok}}$ is the number of oxygen ions per molecule in the stabilizer.

$\mathrm{d}_{\mathrm{O}}$ is the lattice constant from Equation 3.

\subsection{Density of Zirconia with the Addition of Stabilizing Oxides Calcia or Rare Earth Elements}

The density of zirconia mixed with calcia or with one of the rare earth elements (Y, Er, or Gd) listed below is obtained from Equation 3 for the lattice parameter and Equation 5 for the density. The appropriate ionic radii and atomic masses for yttrium, erbium, gadolinium, zirconium, calcium, and oxygen are given in Table 3. [13] 
Table 3 Stabilizing Elements and Their Properties

\begin{tabular}{|c|c|c|}
\hline$\overline{\text { Element }}$ & Ionic Radius & Atomic Mass \\
\hline & $(\mathrm{nm})$ & (g/mole) \\
\hline Zirconium & 0.0800 & 91.230 \\
\hline Oxygen & 0.1400 & 15.999 \\
\hline Calcium & 0.0990 & 40.320 \\
\hline Yttrium & 0.0980 & 88.920 \\
\hline Erbium & 0.0881 & 167.280 \\
\hline Gadolinium & 0.0938 & 157.270 \\
\hline
\end{tabular}

For the binary mixtures of zirconia with the alkaline earth calcium oxide $\left(\mathrm{ZrO}_{2}-\mathrm{CaO}\right)$, the calculated values of the lattice constant and the density are shown in Table 4 . The number of ions per molecule in the calcium oxide stabilizer is 1 . The number of oxygen ions per molecule is also 1 for the calcia stabilizer. The measured densities of calcia in zirconia are between 3 and $5 \%$ lower than the calculated values. This may be due to a smaller contraction of the lattice from the +2 ions compared with the +4 ions in the zirconium matrix or uncertainties in the ionic radii values. Experimental measurements of the lattice constant are not available.

Table 4 Comparison of Density for $\mathrm{ZrO}_{2}-\mathrm{CaO}$ Mixtures

\begin{tabular}{|ccccc|}
\hline $\begin{array}{c}\text { CaO } \\
\text { (mole \%) }\end{array}$ & $\begin{array}{c}\text { Lattice Constant } \\
\text { Calculated (nm) }\end{array}$ & $\begin{array}{c}\text { Density } \\
\text { Calculated }\end{array}$ & $\begin{array}{ccc}\left(\mathbf{k g} / \mathbf{m}^{\mathbf{3}}\right) \\
\text { Measured }\end{array}$ & $\begin{array}{c}\text { Density } \\
\text { Deviation (\%) }\end{array}$ \\
\cline { 2 - 4 } & 0.5125 & 5820.4 & 5530.0 & $5.25 \%$ \\
15.0 & 0.5146 & 5621.6 & 5360.0 & $4.88 \%$ \\
20.0 & 0.5168 & 5427.3 & 5235.0 & $3.67 \%$ \\
22.2 & 0.5178 & 5343.2 & 5118.0 & $4.40 \%$ \\
\hline
\end{tabular}

For the binary mixtures of zirconia with a rare-earth element (erbium, yttrium, or gadolinium oxide), the calculated values of the lattice constant and the density are listed for yttria in Table 5 , for erbia in Table 6, and for gadolina in Table 7. ${ }^{[12]}$ From the general formula $\mathrm{M}_{2} \mathrm{O}_{3}$, the number of cations per molecule of these stabilizers is 2 , and the number of oxygen ions per molecule is 3 .

Table 5 Comparison of Density for $\mathrm{ZrO}_{2}-\mathrm{Y}_{2} \mathrm{O}_{3}$ Mixtures

\begin{tabular}{||cccccc||}
\hline $\begin{array}{c}\text { Yttria } \\
\text { (mole \%) }\end{array}$ & $\begin{array}{c}\text { Lattice } \\
\text { Calculated }\end{array}$ & $\begin{array}{c}\text { Constant } \\
(\mathbf{n m}) \\
\text { Measured }\end{array}$ & $\begin{array}{c}\text { Density } \\
\text { Calculated }\end{array}$ & $\begin{array}{c}\left.\text { (kg/m } \mathbf{3}^{\mathbf{3}}\right) \\
\text { Measured }\end{array}$ & $\begin{array}{c}\text { Density } \\
\text { Deviation (\%) }\end{array}$ \\
35. & 0.5300 & & 5438.2 & 5543.0 & $-1.89 \%$ \\
31.2 & 0.5278 & & 5511.7 & 5603.0 & $-1.63 \%$ \\
26.3 & 0.5254 & & 5595.6 & 5655.0 & $-1.05 \%$ \\
20.0 & 0.5219 & & 5716.4 & 5760.0 & $-0.76 \%$ \\
19.8 & 0.5218 & & 5720.5 & 5800.0 & $-1.37 \%$ \\
17.9 & 0.5207 & 0.5162 & 5760.3 & 5826.0 & $-1.13 \%$ \\
16.5 & 0.5198 & & 5790.7 & 5810.0 & $-0.33 \%$ \\
12.1 & 0.5170 & 0.5146 & 5892.8 & 5932.0 & $-0.66 \%$ \\
11.1 & 0.5164 & 0.5145 & 5917.4 & 5945.0 & $-0.46 \%$ \\
10.0 & 0.5156 & & 5945.2 & 5950.0 & $-0.08 \%$ \\
9.0 & 0.5149 & 0.5150 & 5971.1 & 5980.0 & $-0.15 \%$ \\
8.0 & 0.5142 & 0.5128 & 5997.6 & 5990.0 & $0.13 \%$ \\
6.9 & 0.5134 & 0.5126 & 6027.6 & 6008.0 & $0.33 \%$ \\
\hline
\end{tabular}


Table 6 Comparison of Lattice Parameter for $\mathrm{ZrO}_{2}-\mathrm{Er}_{2} \mathrm{O}_{3}$ Mixture

\begin{tabular}{|c|c|c|c|c|}
\hline \multirow{2}{*}{$\begin{array}{c}\mathrm{Er}_{2} \mathrm{O}_{3} \\
(\mathrm{Mole} \%)\end{array}$} & \multicolumn{2}{|c|}{ Lattice Constant (nm) } & Density $\left(\mathrm{kg} / \mathrm{m}^{3}\right)$ & Lattice \\
\hline & Calculated & Measured & Calculated & Deviation (\%) \\
\hline 6.7 & 0.5104 & 0.5131 & 6627.1 & $-0.52 \%$ \\
\hline 9.0 & 0.5111 & 0.5135 & 6745.4 & $-0.46 \%$ \\
\hline 10.0 & 0.5115 & 0.5140 & 6798.6 & $-0.49 \%$ \\
\hline 13.5 & 0.5125 & 0.5155 & 6967.4 & $-0.58 \%$ \\
\hline 20.0 & 0.5143 & 0.5165 & 7249.7 & $-0.43 \%$ \\
\hline 25.0 & 0.5156 & 0.5177 & 7443.1 & $-0.42 \%$ \\
\hline
\end{tabular}

The measured densities of yttria in zirconia are up to $1.9 \%$ higher than the calculated values. Measured densities of erbia in zirconia are not available, but the measured lattice constant is about $0.5 \%$ higher than the calculated values. Calculated values for the gadolinia additions cannot be compared with experimental values since experimental data are not available.

\subsection{Density of Stabilized Zirconia with Urania}

The model was revised for the additions of urania or plutonia to the lattice. Urania and plutonia are assumed to each have a valence of +4 so that they do not contribute to the creation or destruction of oxygen vacancies in the lattice. Further, since these cations are slightly larger than that of zirconium, the ionic radius of each cation are mass averaged in the lattice. Since erbia is considered for a burnable poison in the weapons-grade plutonium fuel, equations for the lattice constant (Equation 7) and for the density (Equation 8) include erbia.

Table 7 Density of $\mathrm{ZrO}_{2}-\mathrm{Gd}_{2} \mathrm{O}_{3}$ Mixtures

\begin{tabular}{|rcc|}
\hline $\begin{array}{r}\mathbf{G d}_{\mathbf{2}} \mathbf{O}_{\mathbf{3}} \\
(\mathbf{m o l e} \mathbf{\%})\end{array}$ & $\begin{array}{c}\text { Calculated } \\
\text { Latice } \text { Constant } \\
(\mathbf{n m})\end{array}$ & $\begin{array}{c}\text { Calculated } \\
\text { Density } \mathbf{( k g / \mathbf { m } ^ { 3 }}\end{array}$ \\
\hline 35.9 & 0.5249 & 7257.7 \\
31.2 & 0.5232 & 7166.3 \\
26.3 & 0.5213 & 7061.1 \\
20.0 & 0.5187 & 6908.5 \\
19.8 & 0.5186 & 6903.3 \\
17.9 & 0.5177 & 6852.5 \\
16.5 & 0.5171 & 6813.7 \\
12.1 & 0.5149 & 6682.7 \\
11.1 & 0.5144 & 6650.9 \\
10.0 & 0.5139 & 6615.0 \\
9.0 & 0.5133 & 6581.5 \\
8.0 & 0.5128 & 6547.0 \\
6.9 & 0.5122 & 6508.1 \\
\hline
\end{tabular}

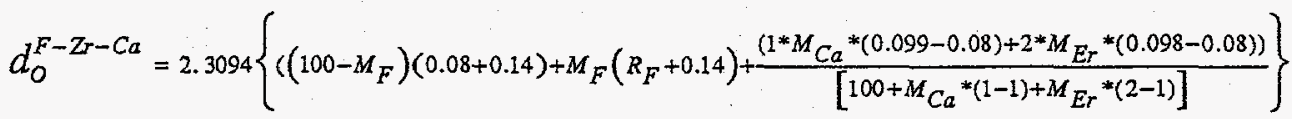

$$
\begin{aligned}
& \rho_{F-C a-E r}=\left\{\frac{4}{\left(10^{\left.-21 * 6.023 * 10^{24 *} d_{0}^{3}\right)}\right.}\right\} \\
& \left\{( 1 0 0 - M _ { F } ) \left((91.23+2 * 15.994)+\left(M_{F}\right)\left(\left(A_{F}+2 * 15.994\right)+\frac{\left(1 * M_{C a}{ }^{*}(40.08-91.23)+2 * M_{E r}{ }^{*}(88.92-91.23)+((1 / 1)+(3 / 2)-2) * 15.994\right)}{100+M_{C a}{ }^{*(1-1)+M_{E r}}{ }^{*(2-1)}}\right\} * 1000\right.\right.
\end{aligned}
$$


Using Equations 6 and 7, the lattice parameter is presented in Table 8 and the density is presented in Table 9 for $\mathrm{UO}_{2}-\mathrm{ZrO}_{2}-\mathrm{CaO}$ fuel mixtures for fuel compositions given by Boltax et al. [1] for the Special Water Reactor (SWR), the Bettis light-water breeder reactor, and for BR-3 tests with the SWR fuel. Also included is the estimated density for the ternary fuel used in the Power Burst Facility (PBF). ${ }^{[14]}$ The theoretical density for the SWR fuel was given as approximately 6000 $\mathrm{kg} / \mathrm{m}^{3}$ although the method of estimating the theoretical density was not given. The densities for the other fuel mixtures were also not given.

Table 8 Lattice Constant for mixtures of $\mathrm{UO}_{2}$ with $\mathrm{ZrO}_{2}$ and $\mathrm{CaO}$

\begin{tabular}{|cccc|}
\hline Fuel Type & $\begin{array}{c}\text { UO } \mathbf{2}_{2} \text { Fertile } \\
\text { Composition } \\
\text { (mole \%) }\end{array}$ & $\begin{array}{c}\text { CaO } \\
\text { Composition } \\
\text { (mole \%) }\end{array}$ & $\begin{array}{c}\text { Lattice Constant } \\
\text { (nm) }\end{array}$ \\
Bettis & 20.24 & 10.25 & 0.5186 \\
BR-3 & 11.83 & 14.77 & 0.5181 \\
SWR & 6.69 & 14.8 & 0.5166 \\
PBF & 13.78 & 12.82 & 0.5179 \\
\hline
\end{tabular}

Table 9 Density for mixtures of $\mathrm{UO}_{2}$ with $\mathrm{ZrO}_{2}$ and $\mathrm{CaO}$

\begin{tabular}{||cccc||}
\hline Fuel Type & $\begin{array}{c}\text { UO2 Fertile } \\
\text { Composition } \\
\text { (mole \%) }\end{array}$ & $\begin{array}{c}\text { CaO } \\
\text { Composition } \\
\text { (mole \%) }\end{array}$ & $\begin{array}{c}\text { Density } \\
\left.\text { (kg/m } \mathbf{3}^{3}\right)\end{array}$ \\
Bettis & 20.24 & 10.25 & \\
BR- & 11.83 & 14.77 & 7034.1 \\
SWR & 6.69 & 14.8 & 6356.3 \\
PBF & 13.78 & 12.82 & 6048.8 \\
\hline
\end{tabular}

Lattice parameters were measured for mixtures of $\mathrm{UO}_{2}$ and $\mathrm{ZrO}_{2}$ with sufficient additions of $\mathrm{CaO}$ to stabilize the cubic structure at high temperatures ${ }^{[15]}$ by $\mathrm{X}$-ray diffraction and are shown in Table 10. The measured and calculated values from Equation 6 agree within about $0.5 \%$.

Densities (Table 11) were calculated from direct measurements and weights of the machined and cleaned specimens. Porosity values were calculated from the bulk, apparent, and true volume relationships. The apparent volume was determined by $\mathrm{CCl}_{4}$ immersion, while the true volume was calculated from the theoretical densities of the compositions. The calculated density is consistently about $7 \%$ higher than the measured density. Some of this difference may be due to difference assumed in the uranium isotopes. Further evaluation is needed in order to improve the model. The densities calculated from Vegard's law are higher by about $20 \%$ than both the calculated densities based on lattice parameters or the measured values demonstrating the erroneous approach using the rule of mixtures. 
Table 10 Comparison of Measured and Calculated Lattice Parameter for Mixtures of $\mathrm{UO}_{2}$ and $\mathrm{ZrO}_{2}$ Stabilized with $\mathrm{CaO}$

\begin{tabular}{|rccccc|}
\hline Fuel Trpe & $\begin{array}{c}\text { UO2 Fertile } \\
\text { Composition } \\
\text { (mole \%) }\end{array}$ & $\begin{array}{c}\text { CaO } \\
\text { Composition } \\
\text { (mole \%) }\end{array}$ & $\begin{array}{c}\text { Lattice Constant (nm) } \\
\text { Calculated }\end{array}$ & $\begin{array}{c}\text { Lattice } \\
\text { Measured }\end{array}$ & $\begin{array}{c}\text { Deviation(\%) } \\
\text { B-1 }\end{array}$ \\
\hline 8.39 & 12.03 & 0.5159 & 0.5158 & $-0.01 \%$ \\
B-2 & 21.45 & 12.15 & 0.5198 & 0.5230 & $0.60 \%$ \\
B-3 & 36.68 & 12.32 & 0.5245 & 0.5270 & $0.48 \%$ \\
BL-3 & 36.68 & 12.32 & 0.5245 & 0.5270 & $0.48 \%$ \\
\hline
\end{tabular}

Table 11 Comparison of Measured and Calculated Density for Mixtures of $\mathrm{UO}_{2}$ and $\mathrm{ZrO}_{2}$ Stabilized with $\mathrm{CaO}$

\begin{tabular}{|c|c|c|c|c|c|c|}
\hline $\begin{array}{l}\text { Fuel } \\
\text { Type }\end{array}$ & $\begin{array}{c}\text { UO2 Fertile } \\
\text { Composition } \\
\text { (mole \%) }\end{array}$ & $\begin{array}{c}\text { CaO } \\
\text { Composition } \\
\text { (mole \%) }\end{array}$ & $\begin{array}{l}\text { Calculated } \\
\text { Density } \\
\left(\mathrm{kg} / \mathrm{m}^{3}\right)\end{array}$ & $\begin{array}{l}\text { Density based } \\
\text { on Mixtures }\end{array}$ & $\begin{array}{l}\text { Measured } \\
\text { Density } \\
\left.\text { (kg/m }{ }^{3}\right)\end{array}$ & $\begin{array}{c}\text { Density } \\
\text { Deviation }(\%)\end{array}$ \\
\hline B-1 & 8.39 & 12.03 & 6262.8 & 7469.0 & 5860 & $-6.87 \%$ \\
\hline B-2 & 21.45 & 12.15 & 7023.7 & 6703.6 & 6580 & $-6.74 \%$ \\
\hline B-3 & 36.68 & 12.32 & 7863.6 & 7066.5 & 7380 & $-6.55 \%$ \\
\hline BL-3 & 36.68 & 12.32 & 7863.6 & 7066.5 & 7380 & $-6.55 \%$ \\
\hline
\end{tabular}

The lattice parameters of a mixture of plutonia in zirconia stabilized with calcia obtained from Equation 6 are listed in Table 12. Experimental measurements of the lattice parameter have not been found. Again, these values are based on $\mathrm{Pu}^{+4}$ without any $\mathrm{Pu}^{+3}$ in the mixture.

Table 12 Lattice Parameter for mixtures of $\mathrm{PuO}_{2}$ with $\mathrm{ZrO}_{2}$ and $\mathrm{CaO}$

\begin{tabular}{|ccc|}
\hline $\begin{array}{c}\mathrm{PuO}_{2} \text { Fertile } \\
\text { Composition } \\
\text { (mole \%) }\end{array}$ & $\begin{array}{c}\text { CaO } \\
\text { Composition } \\
\text { (mole \%) }\end{array}$ & $\begin{array}{c}\text { Lattice } \\
\text { Constant } \\
\text { (nm) }\end{array}$ \\
\hline 1.78 & 12.03 & 0.5140 \\
2.66 & 12.15 & 0.5143 \\
3.80 & 14.27 & 0.5155 \\
4.44 & 12.32 & 0.5148 \\
\hline
\end{tabular}

The density of a mixture of plutonia in zirconia stabilized with calcia is listed in Table 13 . These densities were obtained from Equation 7 using the calculated lattice parameter in Table 12.

Table 13 Density for mixtures of $\mathrm{PuO}_{2}$ with $\mathrm{ZrO}_{2}$ and $\mathrm{CaO}$

\begin{tabular}{|ccc|}
\hline $\begin{array}{c}\mathrm{PuO}_{2} \text { Fertile } \\
\text { Composition } \\
\text { (mole \%) }\end{array}$ & $\begin{array}{c}\text { CaO } \\
\text { Composition } \\
\text { (mole \%) }\end{array}$ & $\begin{array}{c}\text { Density } \\
\left(\mathbf{K g} / \mathbf{m}^{3}\right)\end{array}$ \\
1.78 & 12.03 & 5921.0 \\
2.66 & 12.15 & 5972.3 \\
3.80 & 14.37 & 5960.2 \\
4.44 & 12.32 & 6078.4 \\
\hline
\end{tabular}




\subsection{Thermal Conductivity of $\mathrm{PuO2}$ (or $\mathrm{UO}_{2}$ )-Stabilized $\mathrm{ZrO}_{2}$ Mixtures Using $\mathrm{CaO}$ or $\mathrm{Y}_{2} \mathrm{O}_{3}$}

In a parallel fashion to the development of ternary $\mathrm{UO}_{2}-\mathrm{ZrO}_{2}-\mathrm{CaO}$ fuels, $\mathrm{PuO}_{2}$ may be substituted for $\mathrm{UO}_{2}$ in order to achieve high burnup fuel capability $\left(7.45 \times 10^{20}\right.$ fissions $\left./ \mathrm{cm}^{3}\right)$ and still retain structural integrity. Small amounts of the rare earths may be added to enhance the neutronic performance and contribute to stabilizing the cubic structure. Therefore, a $\mathrm{ZrO}_{2}-\mathrm{CaO}$ matrix is selected as the primary choice for the matrix, with the potential to replace calcia with yttria to enhance fuel performance. The thermal conduction of $\mathrm{UO}_{2}-\mathrm{ZrO}_{2}, \mathrm{UO}_{2}-\mathrm{ZrO}_{2}-\mathrm{CaO}, \mathrm{ZrO}_{2}-\mathrm{CaO}$, and $\mathrm{ZrO}_{2}-\mathrm{Y}_{2} \mathrm{O}_{3}$ mixtures is presented as a basis for the thermal conductivity of $\mathrm{UO}_{2}-\mathrm{ZrO}_{2}-\mathrm{CaO}$, $\mathrm{UO}_{2}-\mathrm{ZrO}_{2}-\mathrm{Y}_{2} \mathrm{O}_{3}, \mathrm{PuO}_{2}-\mathrm{ZrO}_{2}-\mathrm{CaO}$, and $\mathrm{PuO}_{2}-\mathrm{ZrO}_{2}-\mathrm{Y}_{2} \mathrm{O}_{3}$ ternary fuels.

\subsection{Thermal Conduction of $\mathrm{UO}_{2}-\mathrm{ZrO}_{2}$ mixtures}

Thermal diffusivityl ${ }^{[15]}$ of different binary $\mathrm{UO}_{2}-\mathrm{ZrO}_{2}$ fuels is shown in Figure 7. As the amount of urania decreases, the thermal diffusivity of the $\mathrm{ZrO}_{2}-\mathrm{UO}_{2}$ mixtures increases. An anomaly appears to occur when only $6 \%$ zirconia is added to urania resulting in a substantial increase in thermal diffusivity. The data for high concentrations of $\mathrm{UO}_{2}$ show a consistant decrease in thermal conductivity with incresing urania contents.

The data in Figure 7 were converted to thermal conductivity values using the density and heat capacity of these materials. ${ }^{[16]}$ The thermal conductivity of the mixtures with different amounts of $\mathrm{UO}_{2}$ decreases with increasing temperature as with diffusivity (Figure 8). For comparison, the thermal conductivity of $\mathrm{UO}_{2}$ derived from a large data base of $\mathrm{UO}_{2}$ thermal conductivities is also shown in Figure 8.[16] Since the thermal conductivity of urania with $5 \mathrm{wt} \%$ plutonia is coincident with the curve for pure $\mathrm{UO}_{2}$, the binary mixture of plutonia with zirconia and the ternary mixture of plutonia with zirconia and calcia or yttria are expected to be nearly the same as that of the similar alloys with urania. At low temperatures, the thermal conductivity of the binary fuel mixture is about a factor of two below that of pure $\mathrm{UO}_{2}$, but at temperatures near the operating centerline temperatures of the fuel, the thermal conductivity is about $25 \%$ lower than that of $\mathrm{UO}_{2}$.

In order to stabilize the face-centered-cubic structure of $\mathrm{UO}_{2}$ and $\mathrm{ZrO}_{2}$ at high temperature, calcia is added as one of the stabilizing agent. The thermal conductivity of ternary $\mathrm{ZrO}_{2}-\mathrm{UO}_{2}$ mixtures with calcia as a stabilizing agent is shown in Figure 9. The thermal conductivity of the ternary mixture with large concentrations of $\mathrm{UO}_{2}$ is even lower than that of the binary mixture, up to a two fold reduction from that of pure $\mathrm{UO}_{2}$. The reduced thermal conductivity arises from the generation of oxygen vacancies from the introduction of the +2 calcium cation that reduces the mean free path of the photons in the lattice. The low urania or plutonia concentrations in the non-fertile fuels will enhance the thermal conductivity of these ternary fuels.

From the data in Figure 8, the thermal conductivity changes very little for urania concentrations between 4 and 20 mole $\%$. Since this data covers the fissile concentration range for the non-fertile fuel, a least squares fit of the date for urania concentrations indicates thermal conductivity decreasing with increasing temperature as shown by the following equation:

$\mathrm{k}=2.0976-2.0101 \times 10-4 \mathrm{~T}$

where $\mathrm{T}=$ temperature $(\mathrm{C})$ 


\section{Thermal Diffusivity \\ Binary Urania-Zirconia Alloys}

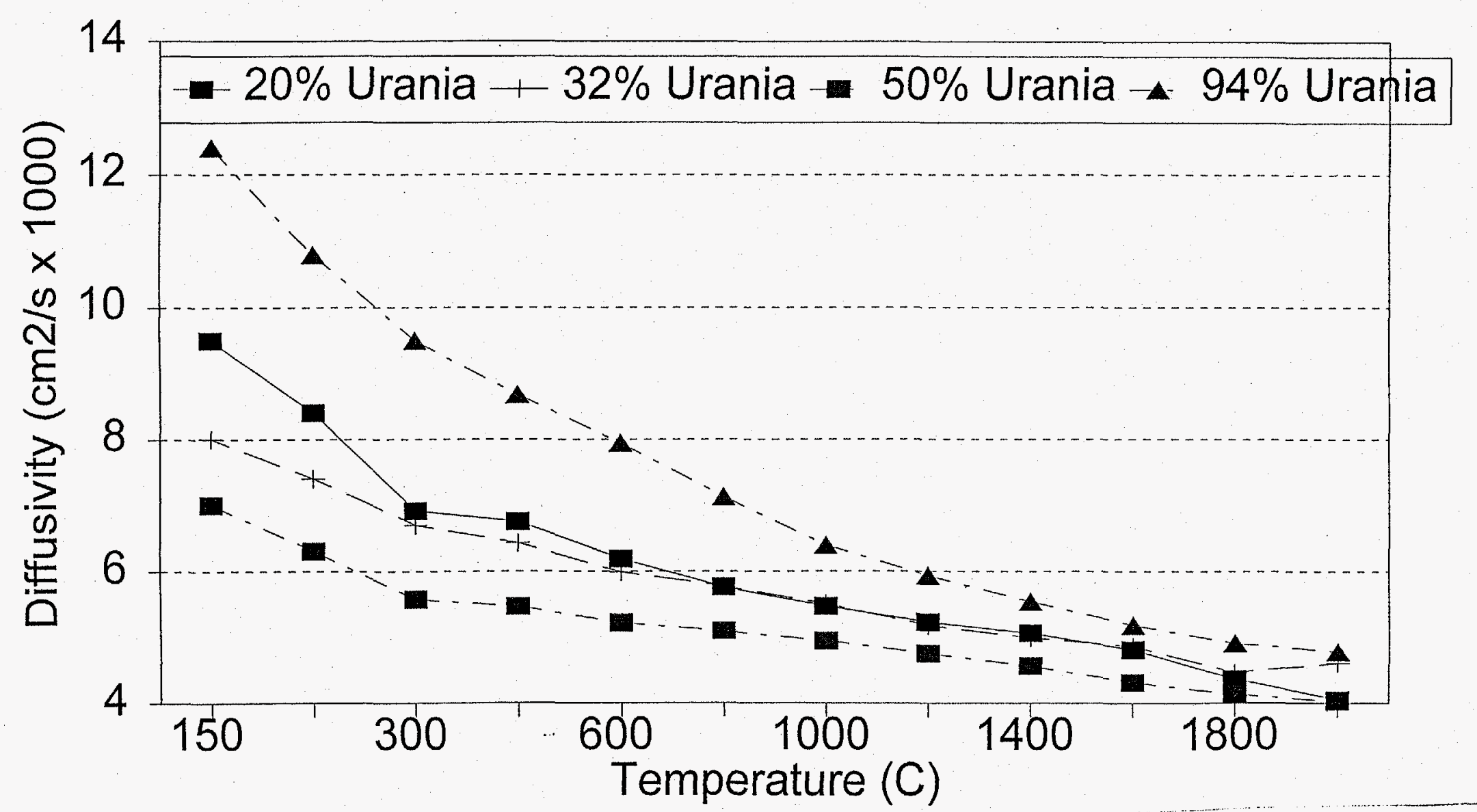

Figure 7 Thermal diffusivity of $\mathrm{UO}_{2}-\mathrm{ZrO}_{2}$ mixtures 


\section{Thermal Conductivity Binary Zirconia-Calcia Alloys}

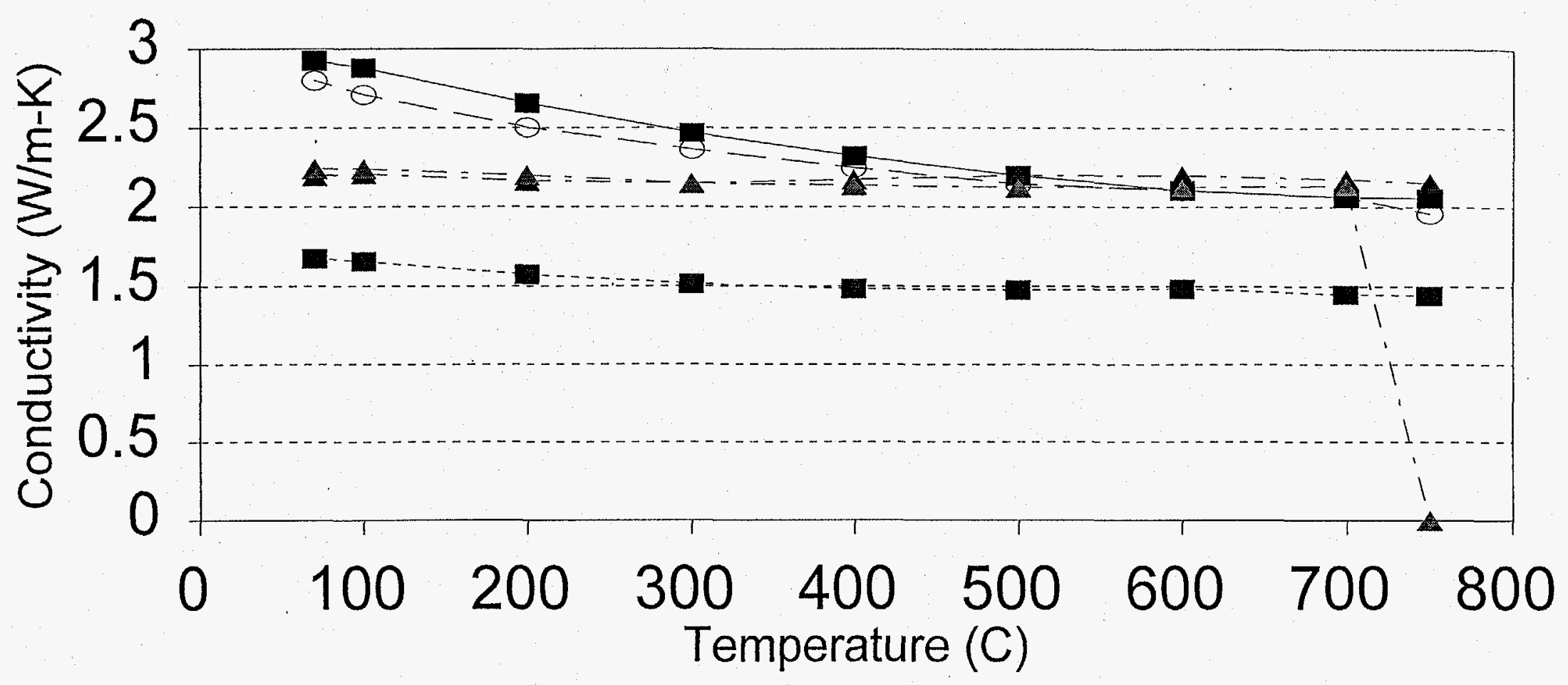

- $5 \mathrm{~mole} \% \mathrm{CaO}-0-7.6 \mathrm{~mole} \% \mathrm{CaO}-10 \mathrm{~mole} \% \mathrm{CaO}$

- $15 \mathrm{~mole} \% \mathrm{CaO}$ - 20 mole $\% \mathrm{CaO}$

Figure 8 Thermal Conductivity of $\mathrm{ZrO}_{2}-\mathrm{UO}_{2}$ mixtures 


\section{Thermal Conductivity}

Ternary Urania-Zirconia-Calcia Alloys

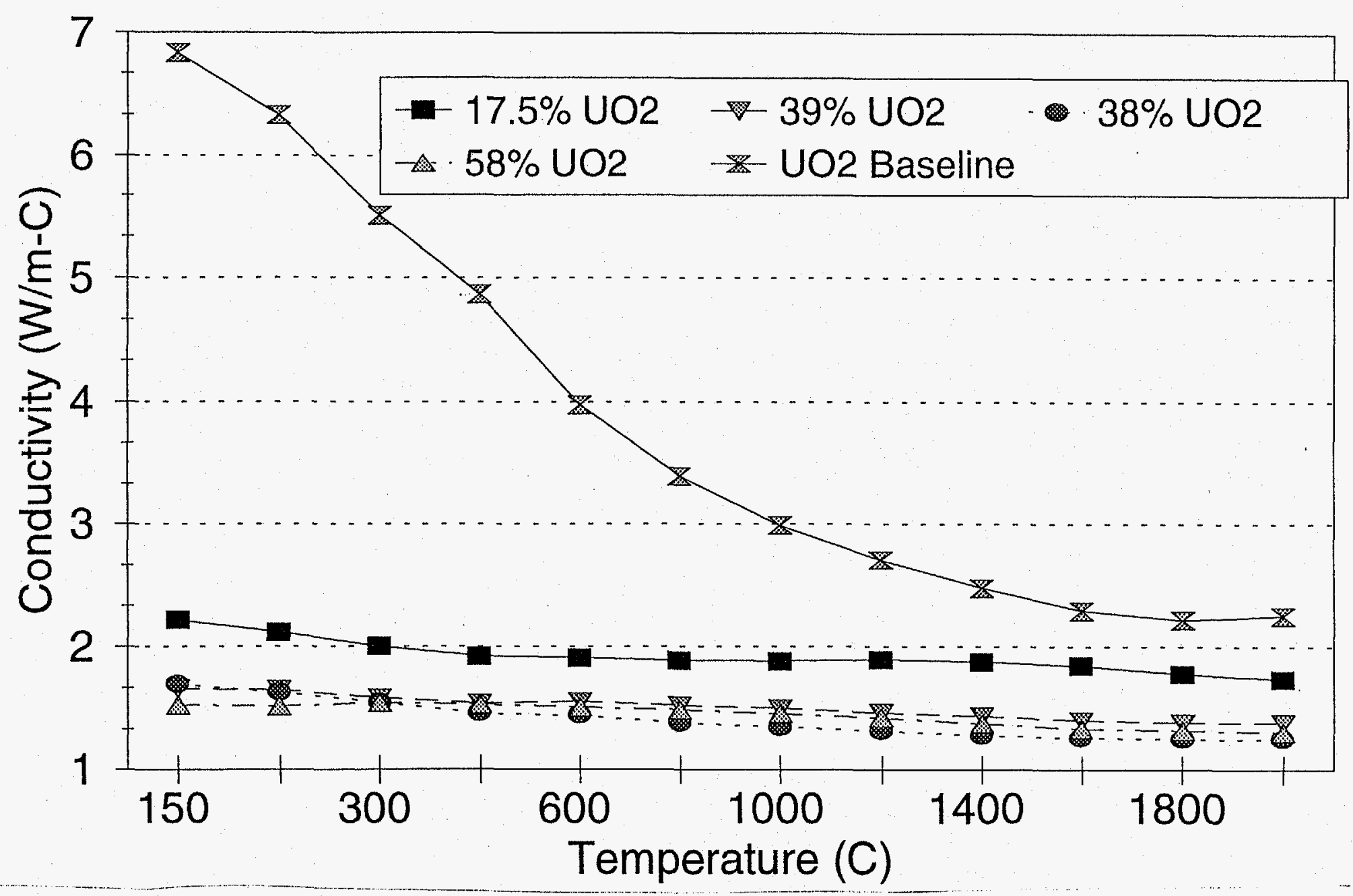

Figure 9 Thermal conductivity of $\mathrm{UO}_{2}-\mathrm{ZrO}_{2}-\mathrm{CaO}$ mixtures 


\subsection{Thermal Conductivity of $\mathrm{ZrO}_{2}$ Binary Mixtures}

The thermal conductivity of a $\mathrm{ZrO}_{2}-\mathrm{CaO}$ mixture without a fissile material is shown in Figure 10. [13] The thermal conductivity decreases with an increase in calcia content up to about 10 mole percent calcia. Then additional calcia appears to have no further effect. The thermal conductivity of yttria behaves similar to that of calcia. [17] Although about $20 \%$ yttria is required to stabilize the cubic structure in zirconia, the thermal conductivity of a solution containing less than $10 \mathrm{~mole} \%$ yttria yields a partially stabilized structure (PSZ) which may have superior mechanical properties to that of a calcia stabilized structure and is expected to have a higher thermal conductivity because of its lower concentration in PSZ.

\subsection{Fuel Temperatures}

Higher fuel temperatures resulting from a lower thermal conductivity may be mitigated by using pellets fabricated with an annulus. Steady-state fuel temperatures based on $\mathrm{UO}_{2}$ thermal conductivity were calculated for both the PWR and BWR fuel designs at $196.85 \mathrm{~W} / \mathrm{cm}(6 \mathrm{~kW} / \mathrm{ft})$ and $393.7 \mathrm{~W} / \mathrm{cm}(12 \mathrm{~kW} / \mathrm{ft})$. Central holes of with diameters of $5 \%, 7.5 \%$, and $10 \%$ of the fuel pellet diameter and a coolant temperature of $310^{\circ} \mathrm{C}$ were assumed. Since these calculations were to examine the effect of a central hole on the centerline temperature, the use of the $\mathrm{UO}_{2}$ thermal conductivity is an adequate assumption, recognizing that the fuel temperatures for a binary or ternary mixture would be higher. The results are shown in Table 14.

Table 14 Fuel temperatures for various annular hole sizes for PWR fuel pellets

\begin{tabular}{|c|c|c|c|c|c|}
\hline \multirow{5}{*}{$\begin{array}{c}\text { Centerline } \\
\text { Hole } \\
\text { Diameter } \\
(\mathrm{cm})\end{array}$} & \multirow{4}{*}{$\begin{array}{c}\text { Ratio Hole } \\
\text { Size to } \\
\text { Fuel }\end{array}$} & \multicolumn{2}{|c|}{$196.85 \mathrm{~W} / \mathrm{cm}$ Power } & \multicolumn{2}{|c|}{393.7 W/cm Power } \\
\hline & & & Temperature & & Temperature \\
\hline & & & Drop & & Drop \\
\hline & & Centerline & Compared & Centerline & Compared \\
\hline & $\begin{array}{c}\text { Diameter } \\
(\%)\end{array}$ & $\begin{array}{c}\text { Temperature } \\
(\mathbf{K})\end{array}$ & $\begin{array}{l}\text { to Solid } \\
\text { Pellet }(\mathrm{K})\end{array}$ & $\begin{array}{c}\text { Temperature } \\
(\mathbf{K})\end{array}$ & $\begin{array}{l}\text { to Solid } \\
\text { Pellet }(K)\end{array}$ \\
\hline 0 & 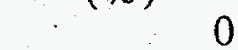 & 1071.7 & 0 & 1822 & 0 \\
\hline 09 & 5 & 1050 & 21.7 & 1759 & 63 \\
\hline 64 & 5.66 & 1045.3 & 26.4 & 1745.5 & 76.5 \\
\hline 0.06 & 7.5 & 103 & 40.5 & 1704.3 & 117.7 \\
\hline 0.08188 & 10 & 1010.1 & 61.6 & 1642.4 & 179.6 \\
\hline
\end{tabular}

For the PWR fuel design, a central hole $5 \%$ of the pellet diameter results in a $21.7^{\circ} \mathrm{C}$ drop in the centerline temperature at $196.85 \mathrm{~W} / \mathrm{cm}(6.0 \mathrm{~kW} / \mathrm{ft})$ power level and $63.0^{\circ} \mathrm{C}$ at $393.7 \mathrm{~W} / \mathrm{cm}$. Increasing the hole diameter to $10 \%$ of the pellet diameter results in $61.6^{\circ} \mathrm{C}$ drop at $196.85 \mathrm{~W} / \mathrm{cm}$ and $179.6^{\circ} \mathrm{C}$ at $393.7 \mathrm{~W} / \mathrm{cm}$. Thus an annular hole is effective in reducing the centerline temperature as well as providing free space for fission gas release. 


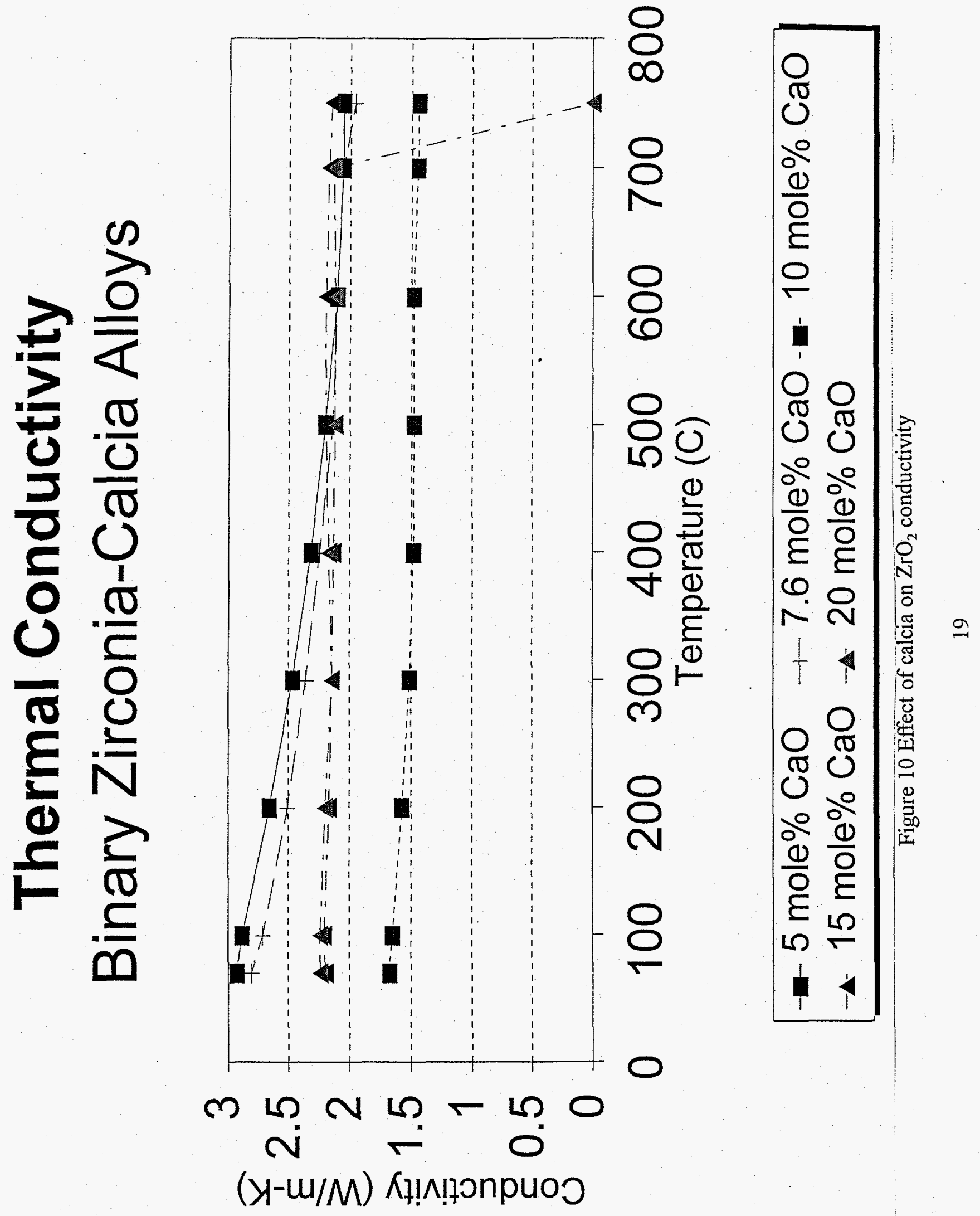


Table 15 Fuel temperatures for various annular hole sizes for BWR fuel pellets

\begin{tabular}{|c|c|c|c|c|c|}
\hline \multirow{3}{*}{$\begin{array}{c}\text { Centerline } \\
\text { Hole }\end{array}$} & \multirow{3}{*}{$\begin{array}{c}\text { Ratio Hole } \\
\text { Size to }\end{array}$} & \multicolumn{2}{|c|}{$196.85(\mathrm{~W} / \mathrm{cm})$ Power } & \multicolumn{2}{|c|}{$393.7 \mathrm{~W} / \mathrm{cm}$ Power } \\
\hline & & & Temperatur & & Temperature \\
\hline & & ine & $\begin{array}{c}\text { Drop } \\
\text { Compared to }\end{array}$ & ine & $\begin{array}{c}\text { Drop } \\
\text { Compared to }\end{array}$ \\
\hline Diameter & Diameter & Temperature & Solid Pellet & Temperature & Solid Pellet \\
\hline$(\mathrm{cm}$ & $(\%)$ & & (K) & & \\
\hline & & & & & \\
\hline 0.0 & & & 21 & & 61 \\
\hline & 7.5 & & 35 & & 11 \\
\hline 1434 & 10.0 & 998.7 & 59.3 & 16 & 173.8 \\
\hline
\end{tabular}

For the BWR fuel design, a central hole $5 \%$ of the pellet diameter results in a $20.9^{\circ} \mathrm{C}$ drop in the centerline temperature at $196.85 \mathrm{~W} / \mathrm{cm}(6.0 \mathrm{~kW} / \mathrm{ft})$ power level and $61.0^{\circ} \mathrm{C}$ at $393.7 \mathrm{~W} / \mathrm{cm}$. Increasing the hole diameter to $10 \%$ of the pellet diameter results in $59.3{ }^{\circ} \mathrm{C}$ drop at $196.85 \mathrm{~W} / \mathrm{cm}$ and $173.8^{\circ} \mathrm{C}$ at $393.7 \mathrm{~W} / \mathrm{cm}$. Thus an annular hole is also effective in reducing the centerline temperature for a BWR fuel pellet as well as providing free space for fission gas release. The fuel temperatures are lower for the BWR fuel pellet than the PWR fuel pellet because of the larger diameter fuel and the same linear power level. 


\subsection{Mechanical Behavior of Partially Stabilized Zirconia (PSZ)}

Although a number of oxides may be used to stabilize the cubic structure of zirconia such as calcia or magnesia, yttria offers the potential to strengthen zirconia by increasing the resistance to microcracking by the transformation of a small amount of the tetragonal phase to the monoclinic phase in a partially stabilized zirconia (PSZ). Although in pure zirconia, the $3 \%$ expansion during the phase shift is sufficient to severely weaken and fracture the zirconia, zirconia that is only partially stabilized, exhibits higher strength than the zirconia that is completely stabilized to the cubic fluorite structure.

Retention of the tetragonal structure is the key factor for fabricating a tougher material based on the transformation-toughening concept. ${ }^{[18]}$ In brittle materials, the transformation usually occurs as the polycrystalline body is cooled through it's transformation temperature; this produces a highly microcracked body. Stresses that arise from the shape change associated with the transformation cause these microcracks. Retention of the tetragonal phase is viewed in terms of constraint of this shape change. Constraint can arise from two sources. First, if the polycrystalline body were single phase, neighboring grains, each with a different crystallographic orientation, could constrain the anisotropic shape change of one another. Second, if a particle of the material were surrounded by a matrix of another material, the matrix material could constrain the particle shape change. If the transformation were to take place, stresses that arise from the constraint would alter the transformation thermodynamics from the familiar, unconstrained case. These stresses can also cause microcrack development which must be avoided to maintain the constraint.

The critical stress intensity factor based upon the constraint is given by:

$$
K_{C}=\left[K_{o}^{2}+\frac{2 k\left(\frac{\Delta V}{V}\right)^{2} E_{C} V_{P} R}{3\left(1-v_{C}^{2}\right)}\right]^{\frac{1}{2}}
$$

The contribution of the stress-induced fracture toughness will depend on the elastic constraining factor, $\mathrm{k}$, the shape change associated with the transformation, $\frac{\Delta V}{V}$, the elastic constants of the constraining material, $\mathrm{E}_{\mathrm{c}}$, the volume fraction of the metastable phase, $\mathrm{V}_{\mathrm{P}}$, and the radius of the process zone, $\mathrm{R}$. $\mathrm{K}_{\mathrm{C}}$ for zirconia partially stabilized by yttria as a function of the volume fraction of tetragonal zirconia is shown in Figure 12 for values of the various parameters shown in the figure. Nearly perfect agreement is obtained for zirconia stabilized with yttria although not as good agreement was obtained with zirconia and alumina. 


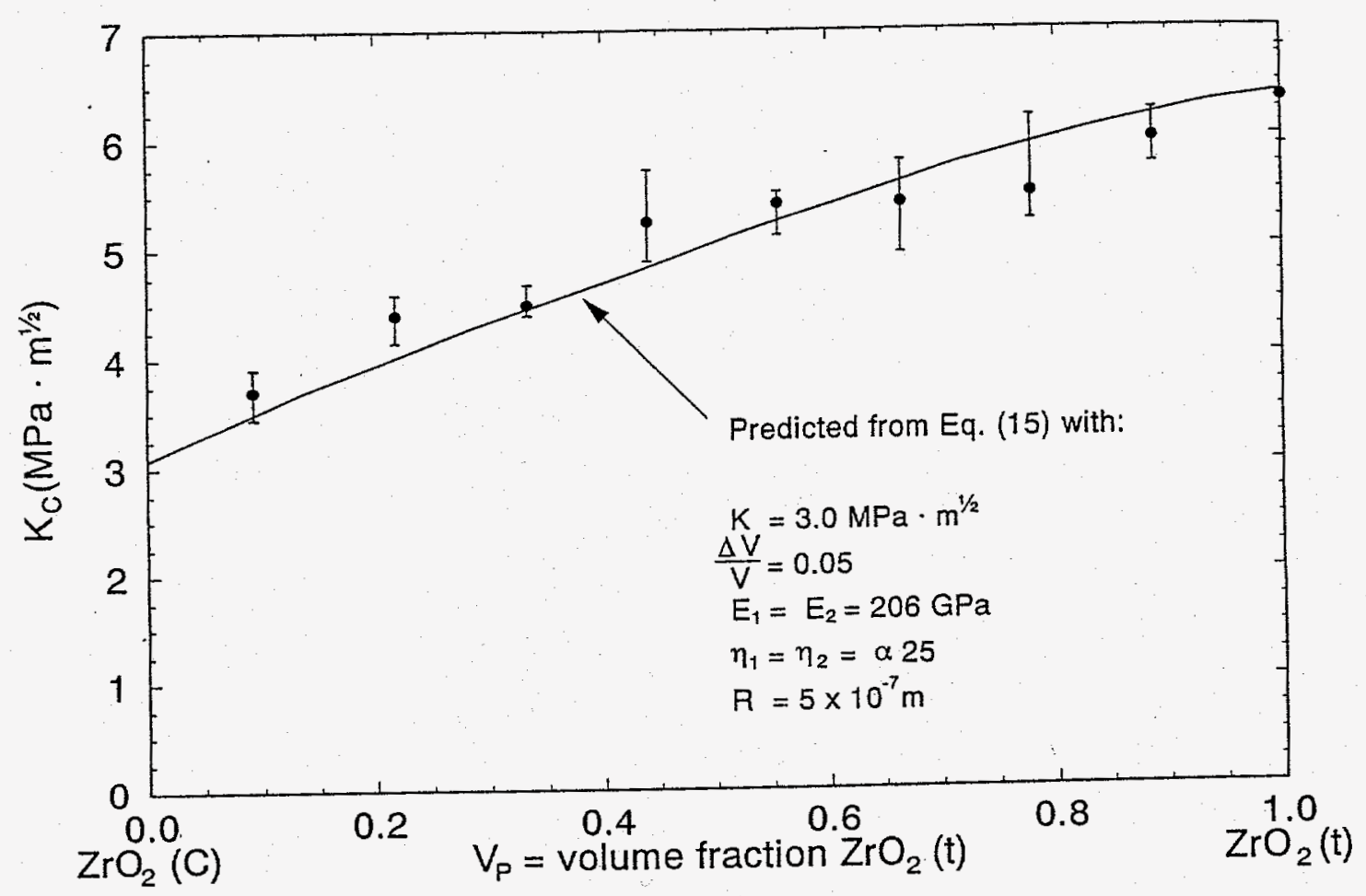

Figure 11 Fracture strength of partially stabilized zirconia with yttria 


\subsection{Irradiation Behavior}

In addition to the need to have high mechanical strength and resistance to microcracking discussed above, the retention of mechanical integrity is based on the dispersion of a fissile material (uranium or plutonium) in a matrix which itself does not deteriorate under neutron irradiation which implies materials with low neutron cross sections. An example of a deteriorating matrix is the use of carbide fuels dispersed in a graphite matrix for space applications. Fission fragment damage occurred to the graphite matrix by the surrounding fissile materials. An analogous case is the potential limitation to high burnups in PWR and BWR fuels from the absorption of neutrons and the resultant damage to the U-238 matrix containing fissile U-235 fuel.

A number of materials may be selected for the matrix material for dispersing urania or plutonia. such as alumina $\left(\mathrm{Al}_{2} \mathrm{O}_{3}\right), \mathrm{BeO}$, zirconia, calcia, or yttria. Because of the previous development of the urania-zirconia-calcia fuels, zirconia-calcia was selected as the matrix material from which to expand the technology to plutonia substituted for urania. Alumina has been suggested as a matrix material $[20\}$ because of its high thermal conductivity, but significant swelling of $\mathrm{Al}_{2} \mathrm{O}_{3}$ irradiated at high temperature is attributable to the unfaulting of interstitial dislocation loops and the formation of networks which serve as efficient sinks for conversion of interstitial point defects to lattice atoms. Anisotropic growth of polycrystalline alumina can cause microcracking which limits the usefulness of this ceramic in high-temperature, high-dose applications. ${ }^{[21]}$

$\mathrm{ZrO}_{2}-\mathrm{UO}_{2}$ plate-type fuel elements with a wide range of $\mathrm{UO}_{2}$ loadings were tested in pressurized water loops over a range of surface heat flux values. $[22,23]$ The $\mathrm{ZrO}_{2}$-base fuels were found to be extremely plastic during irradiation and to undergo densification to essentially $100 \%$ theoretical density very shortly after irradiation began. Irradiation-induced phase changes were observed by $\mathrm{X}$-ray diffraction, with multiphase compositions homogenizing into a single metastable phase with the fluorite-type structure. Fission gas precipitates internally as bubbles, beginning at an early stage of irradiation. The in-pile fuel swelling is linear with exposure, after correction for initial densification, up to $40 \times 10^{20}$ fissions/cc and was determined to be $0.7 \% \Delta V / V$ per $10^{20}$ fissions/cc for compositions between 25 and $46 \mathrm{wt} \% \mathrm{UO}_{2}$ and temperatures between 704 and $1260^{\circ} \mathrm{C}$.

Postirradiation measurements had been made at 700 to $1500{ }^{\circ} \mathrm{C}$ of the release of ${ }^{133} \mathrm{Xe}$ recoiled into single-crystal $\mathrm{Al}_{2} \mathrm{O}_{3}, \mathrm{BeO}, \mathrm{MgO}$, and $\mathrm{ZrO}_{2}$ crystals during neutron irradiation in contact with $\mathrm{UO}_{2}$ powder. ${ }^{[24]}$ Diffusion coefficients for ${ }^{133} \mathrm{Xe}$ have been calculated from the slope of the release curve following the initial release. The activation energy for ${ }^{133} \mathrm{Xe}$ release from $\mathrm{Al}_{2} \mathrm{O}_{3}$ above $1100{ }^{\circ} \mathrm{C}$ was $65 \mathrm{kcal} / \mathrm{g}$-mole. The xenon release behavior had been compared to anion diffusion in these oxides.

For most oxides there are two release processes, an initial rapid release which persists for several minutes only, and slower release over hours during which the accumulative fraction of xenon released is linear with the square root of the heating time. The mechanism of the initial rapid release has not been determined. Diffusion coefficients calculated form the slope of the release curve during the slower release agree in magnitude with anion diffusion coefficients measured for the same oxides over the temperature range of $1100^{\circ} \mathrm{C}$ to $1500^{\circ} \mathrm{C}$. The activation energy of 64 $\mathrm{kcal} / \mathrm{g}$-mole is reported for an extrinsic or impurity controlled diffusion process.

The fused, pure zirconia specimens gave release behavior similar to alumina. The initial rapid process was observed for both first and second heat treatments of these samples, and after several minutes of heating, the accumulative fractional release was linear with the square root of heating 
time. The release curves for single heating of fused calcia-stabilized zirconia showed an initial rapid release followed by a fractional release which was linear with the square root of the heating time with no evidence of an initial rapid process. The single crystal zirconia samples, both pure and yttria stabilized had release curves similar to alumina, initial rapid process evident in both first and second heating with subsequent accumulative fraction release being linear with the square root of the heating time. The magnitudes of the diffusion coefficients above $1100^{\circ} \mathrm{C}$ for $\mathrm{Al}_{2} \mathrm{O}_{3}, \mathrm{BeO}$ and $\mathrm{MgO}$ were nearly the same whereas the diffusion coefficients in $\mathrm{ZrO}_{2}$ were ten to a hundred times larger than that of alumina.

Although the measurements discussed above indicated diffusion through the anion vacancies as the rate controlling mechanism, preponderance of other measurements similar to those discussed above and shown in Table.16 indicate that rate controlling mechanism is diffusion through the cation vacancies as evidenced by the high activation energy which is the similar process in UO2. [25-28] All the measurements but two are in the range from 89 to $99 \mathrm{kcal} / \mathrm{mole}$. The highest is for hafniaerbia system which is expected to be similar to that of zirconia-based alloys and the lowest is for a zirconia-calcia-yttria system which must be regarded as an outlier. Because the composition is similar to that for the non-fertile fuels, the values for $D_{0}$ and $Q$ of $8.3 \times 10^{-2}$ and $99 \mathrm{kcal} / \mathrm{mole}$ respectively for the composition $1 \mathrm{UO}_{2}-1 \mathrm{Y}_{2} \mathrm{O}_{3}-1 \mathrm{ZrO}_{2}$ were used to revise the FASTGRASS code[29] as a mechanistic model for fission product release. These values correspond to a diffusion rate that is about two orders of magnitude higher than that of urania. Minor changes were also made for the atom volume based on the density of the non-fertile fuel and fission product yields for plutonium in addition to those for uranium.

Table 16 Measured Diffusion Coefficients for Cation Diffusion

\begin{tabular}{|c|c|c|c|c|}
\hline System & $\begin{array}{c}\text { Do } \\
\left(\mathrm{cm}^{2} / \mathrm{sec}\right)\end{array}$ & $\begin{array}{c}\mathrm{Q} \\
(\mathrm{kcal} / \mathrm{mole})\end{array}$ & Species & Reference \\
\hline $1 \mathrm{UO}_{2}-1.5 \mathrm{Y}_{2} \mathrm{O}_{3}$ & $7.2 \times 10^{-3}$ & 89 & Xenon & 25 \\
\hline $4 \mathrm{UO}_{2}-1 \mathrm{Y}_{2} \mathrm{O}_{3}$ & $1 / 6 \times 10^{-2}$ & 96 & Xenon & 25 \\
\hline $1 \mathrm{UO}_{2}-1 \mathrm{Y}_{2} \mathrm{O}_{3}-1 \mathrm{ZrO} 2$ & $8.3 \times 10^{-2}$ & 99 & Xenon & 25 \\
\hline $\mathrm{HfO}_{2}-\mathrm{Er}_{2} \mathrm{O}_{3}$ & & $185-153$ & & 26 \\
\hline $\mathrm{ZrO}_{2}-\mathrm{CaO}-\mathrm{Y}_{2} \mathrm{O}_{3}$ & $8.5 \times 10^{-8}$ & 42 & Xenon & 27 \\
\hline $\mathrm{ZrO}_{2}-\mathrm{UO}_{2}$ & 15 & 92 & Xenon & 28 \\
\hline
\end{tabular}

Fission product releases were calculated for the noble fission gases, tellurium, iodine, cesium, barium, and strontium as a function of centerline fuel temperatures corresponding to different power densities in the fuel. These calculations were performed for both BWR and PWR fuel designs to determine fission gas behavior in non-fertile fuel and in $\mathrm{UO}_{2}$ as a reference case. Since the effect of temperature was of primary importance, the temperature gradient was set to a small value of $3^{\circ} \mathrm{C}$.

The results of the FASTGRASS calculations are shown in Figure 13 for the PWR case. The BWR case exhibited similar behavior, but the temperatures are slightly lower because of the lower volumetric power density. At low fuel temperatures, the release from $\mathrm{UO}_{2}$-based fuels are slightly higher than those for the non-fertile fuels, but as the temperature increases, the release from the non-fertile fuel exceeds that of $\mathrm{UO}_{2}$-based fuels. From the standpoint of being able to retain fission products, the non-fertile fuel is not as good as the $\mathrm{UO}_{2}$ fuels, but more importantly is maintaining the cladding strain below the $1 \%$ maximum allowed by NRC. In this sense, enhanced fission product release is desirable. Qualification testing would quantify the better approach; retention versus release of the fission products. 


\section{Fission Product Release}

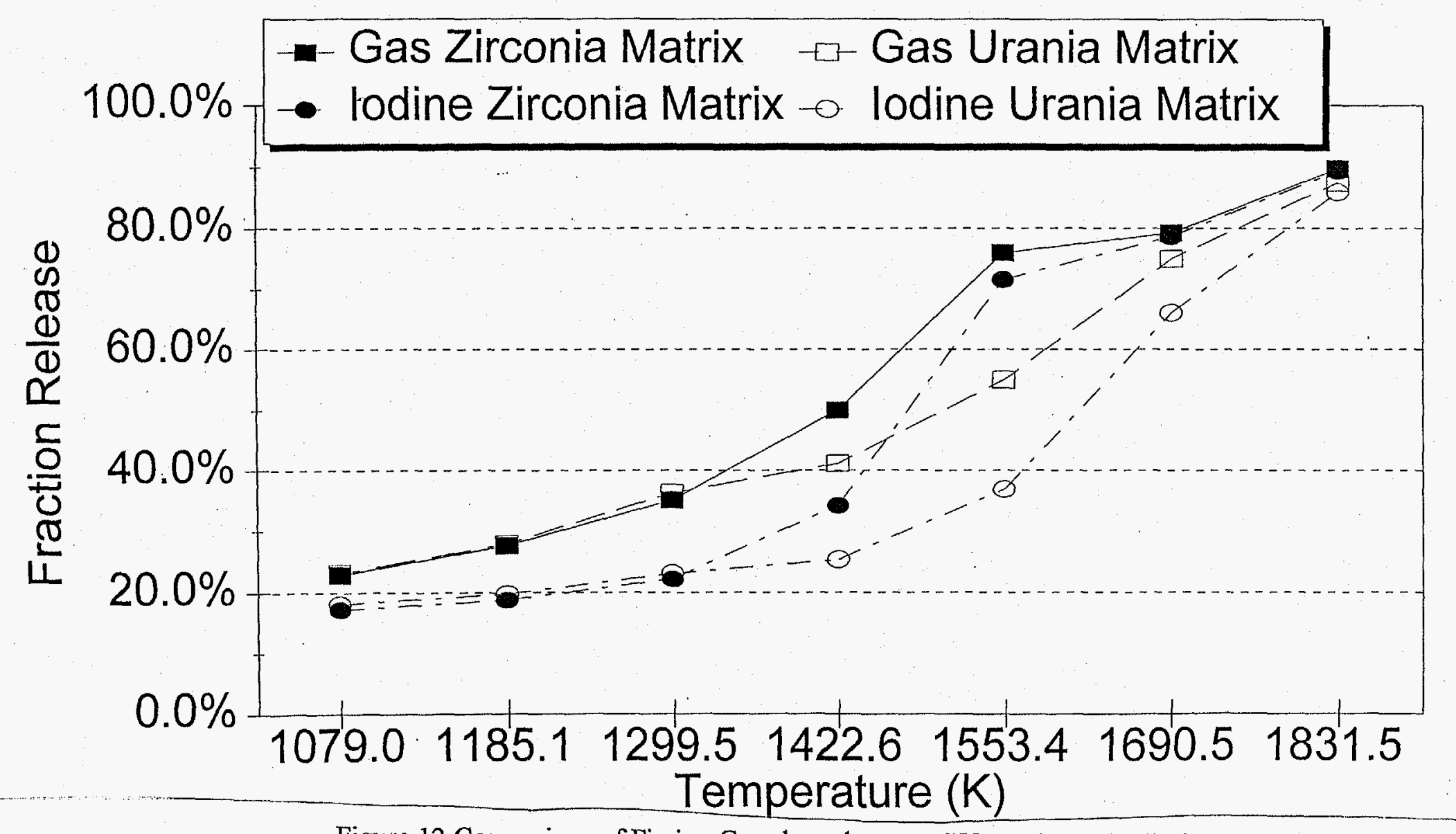

Figure 12 Comparison of Fission Gas elease between $\mathrm{UO}_{2}$ and non-fertile fuel 
FRAPCON $[30]$ calculations were performed for the non-fertile fuel design but using $\mathrm{UO}_{2}$ as a reference case for a low power case with average power levels at $229 \mathrm{~W} / \mathrm{cm}$ for beginning of life (BOL) and decreasing to $164 \mathrm{~W} / \mathrm{cm}$ at end of life (EOL). A high-power case was also performed with average power levels at $312 \mathrm{~W} / \mathrm{cm}$ for BOL and decreasing to $246 \mathrm{~W} / \mathrm{cm}$ at EOL. The PWR fuel rod was prepressurized to $345 \mathrm{psi}$ with a $2200 \mathrm{psi}$ external coolant pressure.

For the high-power case, the peak fuel temperatures at BOL was $2051 \mathrm{~K}$ and 1495 at EOL. The radial gas gap closed increasing the gap conductance and lowering the free void volume in the fuel rod. As a result the fission gas pressure inside the rod reached $1900 \mathrm{psi}$. The cladding hoop strain was still in compression because of the higher 2200 psi coolant pressure. Fission gas release was $6.1 \%$.

For the low-power case, the peak fuel temperatures at BOL was $1680 \mathrm{~K}$ and 1163 at EOL. The radial gas gap closed increasing the gap conductance and lowering the free void volume in the fuel rod. As a result the fission gas pressure inside the rod reached $1800 \mathrm{psi}$. The cladding hoop strain was still in compression. Fission gas release was $3.9 \%$ consistent with the lower fuel temperatures.

Similar results were obtained for the BWR fuel design using $\mathrm{UO}_{2}$. The fuel temperatures were higher than that of the PWR fuel although the volumetric power density was less because the radial gas gap did not close. The fission product release was slightly lower $2.5 \%$ and the fission gas pressure was substantially reduced because of maintaining the void volume in the radial gas gap. Because of the gas gap the internal pressure was reduced to $168 \mathrm{psi}$. 


\subsection{Fuel Qualification}

Based upon the fuel development and testing plans developed for the Space Exploration Initiative $(\mathrm{SEI})^{[31]}$, a non-fertile fuel could be ready for qualification testing in a commercial reactor in about four years. Initial fuel qualification will require testing small fuel samples prepared by different processes and exhibiting different characteristics to determine the optimum fuel fabrication process and validate the expected fuel performance. Further testing will involve testing individual small fuel rod segments or bundles of segments to further expand the fuels performance data base for the non-fertile fuel. Because statistical testing requires a very large number of samples and irradiation facilities are extremely expensive, the approach is to minimize the nuclear testing and to establish the confidence limits by establishing failure mechanisms and models for these mechanisms with their uncertainties. A statistical failure rate for this fuel can then be established. Validation of the fuel performance is done by testing a large number of fuel rods in a commercial reactor. 


\subsection{Conclusions}

The use of urania-zirconia-calcia fuels with high uranium concentration in three reactors during the 1970 s and 1980s established a basis for the development of a plutonia-zirconia-calcia fuel and a urania-zirconia-calcia fuel with lower concentrations of uranium than that previously used. The existing data on phase equilibria of the plutonia-zirconia-calcia or yttria and the urania-zirconiacalcia or -yttria systems were obtained and evaluated for feasible fissile concentrations and concentrations of the matrix materials. Based on the urania ternary fuels and neutronic calculations, the composition of the ternary fuel containing urania or plutonia is $8.3 \mathrm{wt} \%$ urania or plutonia, $80.4 \mathrm{wt} \%$ zirconia, $9.7 \mathrm{wt} \%$ calcia, and $1.6 \%$ erbia. For yttria replacing calcia, the same fissile and erbia contents are retained, and the yttria content varies from $9.9 \mathrm{wt} \%$ to $30.4 \mathrm{wt} \%$ with the zirconia varying from 80.2 to $59.7 \mathrm{wt} \%$.

Since the melting point of plutonia (about $2350^{\circ} \mathrm{C}$ ) is lower than that of $\mathrm{ZrO}_{2}$, the addition of zirconia increases the melting point of the fuel mixture about $125 \mathrm{~K}$. Ternary phase diagram for either the urania or plutonia based fuels using yttria in place of calcia could not be derived since the urania-yttria and the plutonia-yttria phase diagrams are needed and are not available. In addition, the plutonia-zirconia-calcia phase diagram could not be derived because the plutonia-calcia phase diagram is not available. Experimental determinations would have to be performed for these phase diagrams. Although the phase diagrams are incomplete, sufficient data was available to indicate that plutonia may be better than even urania in forming a complete solid solution with zirconia.

A potential improvement in the HEU or plutonia fuels is the substitution of ytria for calcia. Ytria lowers the tetragonal to monoclinic transformation temperature from $850^{\circ} \mathrm{C}$ for calcia to $275^{\circ} \mathrm{C}$ for yttria. In addition, yttria does not lower the liquidus temperature from the melting point of zirconia near $2700^{\circ} \mathrm{C}$. However, if the mechanical properties of partially stabilized zirconia with yttria proves favorable, the yttria content may be reduced resulting in higher thermal conductivity of the ternary fuel.

A model to calculate density of a mixture of the constituents was developed for the addition of urania or plutonia to a stabilized zirconia mixture. Because the creation of anion vacancies from the addition of burnable poisons or stabilizing agents to zirconia, density estimates based on Vegard's law result in unusually $20 \%$ higher values of density estimates than measured densities. The densities or lattice constants for the binary mixture of $\mathrm{ZrO}_{2}$ with calcia or one of the rare earth oxides is within 5\% of the measured values, indicating the applicability of the model to binary mixtures of alkaline earth or rare earth oxides with zirconia.

The results of adding urania or plutonia to binary mixtures of zirconia and calcia are not as good as those of the binary mixtures ( $7 \%$ compared with 5\%), but at this point in developing advanced fuels based on these ternary mixtures, the 7\% error is acceptable. Experimental data on the densities and lattice parameters are needed for the various isotopic mixtures and different oxidation states of the fuel.

A theory has been developed for predicting transformation strengthening of partially stabilized zirconia, and although the theory has been substantiated for zirconia stabilized with yttria, it has not been verified in all systems such as zirconia mixed with alumina. This increase in mechanical properties arises from improved microcracking resistance resulting from the blunting of cracks by the transformation of the tetragonal phase to the monoclinic phase. The use of yttria to stabilize zirconia instead of calcia appears to be beneficial step because of the additional constraint that yttria offers and the lower transformation temperature. Although data are not available for the reduction of microcracking of fissile loaded zirconia-yttria alloys, the available data indicates that yttria will be a substantial improvement over calcia stabilized zirconia fuel matrix. 
The mechanical integrity of the fuel matrix is enhanced by the selection of materials with low cross sections that will not be damage by irradiation. For this reason the selection of zirconia, calcia, or yttria all exhibit good irradiation resistance. On the other hand, inspite of its good thermal conductivity, alumina is extensively damaged by fission fragments when surrounded by a fissile material. 


\subsection{References}

1. U. S. Congress, Office of Technology Assessment, Dismantling the Bomb and Managing the Nuclear Materials, OTA-0-572, Washington D. C., U. S. Government Printing Office, September 1993.

2. Management and Disposition of Excess Weapons Plutonium, Committee on International Security and Arms Control, National Academy of Sciences, National Academy Press, Washington D. C. 1994.

3 Boltax, A., et al, SWR Ternary Fuel Performance, WSR-84-252, December 1984.

4.J. W. Sterbentz, Neutronic Evaluation of a Non-Fertile Fuel for the disposition of Weapons-Grade Plutonium in a Boiling Water Reactor, INEL-94/0079, Óctober 1994.

6. J. H. Handwerk, G. D. White, and D. C. Hill, "Ceramic Nuclear Fuels in the System $\mathrm{UO}_{2}$ $\mathrm{ZrO}_{2}-\mathrm{CaO}^{\prime \prime}$ J. Amer. Ceramic Soc. 40 (1), P. 29-32, Jan. 1963.

6. W. A. Lambertson and M. H. Mueller, Uranium Oxide Phase Equilibrium Systems: III, UO $2^{-}$ $\mathrm{ZrO}_{2}$, J. Amer. Ceramic Soc. 36 (11), p. 365-368, Nov 1953.

7. N. M. Voronov, E. A. Voitekhova, and A. S. Danilin, "Phase Equilibrium Diagrams of Systems $\mathrm{UO}_{2}-\mathrm{ZrO}_{2}$ and $\mathrm{ThO}_{2}-\mathrm{ZrO}_{2}$ ", Second United Nations International Conference on the Peaceful Uses of Atomic Energy, August 4, 1958.

8. K. A. Romberger, C. F. Baes, Jr., and H. H. Stone, Phase Equilibrium Studies in the UO2ZrO2 Syuustem, ORNL-P-2792, Feb. 1967.

9. V. S. Stubican and S. P. Ray, "Phase Equilibria and Ordering in the System $\mathrm{ZrO}_{2}-\mathrm{CaO}$ ", J. Amer. Ceramic Soc. 60 (11-12), p. 534-537, Nov-Dec 1977.

10. D. F. Carroll, The System PuO2-ZrO2, HW-69305, April 1961.

11. A. G. Karaulov, I. N. Rudyak, N. M. Taranukha, and L. I. Glushko, "Formation of Solid Solutions by Yttrium Oxide with Zirconium Dioxide and Hafnium Dioxide", Inorganic Materials 10 (7) P. 1101, July 1974.

12 Ingel, R. P. \& Nakamura, H. H., "Thermal Expansion Behavior of Single-Crystal Zirconia", J. Amer. Cer. Soc., 68 (8), p. C184 - C187, Aug. 1965.

13. V. V. Mirkovich and T. A. Wheat, "Thermal Transport Properties of CaO-stabilized zirconia with varying amounts of stabilization", High Temperatures-High Pressures 17. P. 67-73, 1985.]

14. Cole, J. T. and Wood, R. E., "Power Burst Facility Fuel Studies:, Nucl. Tech. 28, p. 9, Jan. 1978.

15. H. W. Deem, Fabrication, Characterization, and Thermal-Property Measurements of ZrO2Base Fuels, BMI-1775, June 7, 1966.

16. J. K. Hohorst, SCDAP/RELAP5/MOD2 Code Manual Volume IV: MATPRO - A Library of Materials Properties for Light-Water-Reactor Accident Analysis, NUREG/CR-5273 EGG 2555, Vol IV, Janurary 1990. 
17. G. E. Youngblood, "Thermal Diffusivity of Partially and Fully Stabilized (Yttria) Zirconia Single Crystals", J. Amer. Ceram. Soc. 71 (4), p. 255-60, April 1988.

18. F. F. Lange, Phase Retention and Fracture Toughness of Materials Containing Tetragonal $\mathrm{ZrO} 2$, Mechanic al Behavior of Materials Proceedings of the 3rd International conference, Cambridge, England, August 20-24, 1979 P. 45-56, August 1979.

19. P. G. Valentine, R. D. Maier, T. E. Mitchell, Microstructure and Mechanical Properties of Bulk Yttria-Partially-Stabilized Zirconia, NASA-CR-164838, June 1981.

20. H. Akie, T. Muromura, H. Takano, and S. Matsuura, "A New Fuel Material for OnceThrough Weapons Plutonium Buming", Nucl. Tech. 107, P. 182-192, Aug., 1994.

21. Clinard, F. W., Bunch, J. M., Ranken, W. A., Neutron Irradiation Damage in A12O3 and Y2O3, LA- UR-75-1840, 1975.

22. B. F. Rubin, R. M. Berman, and M. L. Bleiberg, The Irradiation Behavior of ZrO2-UO2 Fuels, WAPD-254, October 1962.

23. R. M. Berman, The Homogenization and Densification of $\mathrm{ZrO} 2+\mathrm{UO} 2$ Fuels under Irradiation, WAPD-301, January 1966.

24. D. L. Morrison, T. S. Elleman, \& D. N. Sunderman, "Diffusion of Xenon in Ceramic Oxides", J. Appl. Physics, 31, (4), p. 1616-1622, May 1964.

25. D. R. Lichtenberger, "Xe-133 Diffusion in Urania Solid Solutions", GE-TM-65-4-40, May 3, 1965. Presented at American Ceramic Society Meeting, Philadelphia Pa, May 3, 1965. COnF 650513-10.

$26 \mathrm{R} . \mathrm{J}$. Tesch, Self diffusion of $\mathrm{Hf}$ in $\mathrm{Er}_{2} \mathrm{O} 3$-doped polycrystalline $\mathrm{HfO} 2$, Iowa State University, Ames, Iowa, 1981.

27. D. L. Morrison et al., Postirradiation Release of Xe133 from Oxide Ceramics, BMI

28. J. C. Clayton, The Evolution of Xenon-133 from Slightly Irradiated Zirconia-Urania Plates, WAPD-TM-313, August 1963.

29. J. Rest and S. A. Zawakski, FASTGRASS: A Mechanistic Model for the Prediction of Xe, I. $\mathrm{Cs} . \mathrm{Te}, \mathrm{Ba}$, and $\mathrm{Sr}$ Release from Nuclear Fuel under Normal and Severe Accident Conditions, NUREG/CR-51840 ANL-92/3, September 1992

30. G. A. Berna, M. P. Bohn, W. N. Raausch, R. E. Williford, D. D. Lanning, FRAPCON-2: A Computer Code for the Calculation of Steady State Thermal-Mechanical Behavior of Oxide Fuel Rods, NUREG/CR-1849, December 1980.

31. C. S. Olsen, et al., Space Exploration Initiative Fuels, Materials, and Related Nuclear Propulsion Technologies Panel, NASA Technical Memorandum 105706, September 1993. 